\title{
DISCLAIMER
}

This report was prepared as an account of work sponsored by an agency of the United States Government. Neither the United States Government nor any agency thereof, nor any of their employees, makes any warranty, express or implied, or assumes any legal liability or responsibility for the accuracy, completeness, or usefulness of any information, apparatus, product, or process disclosed, or represents that its use would not infringe privately owned rights. Reference herein to any specific commercial product, process, or service by trade name, trademark, manufacturer, or otherwise does not necessarily constitute or imply its endorsement, recommendation, or favoring by the United States Government or any agency thereof. The views and opinions of authors expressed herein do not necessarily state or reflect those of the United States Government or any agency thereof.

\section{THE PUBLIC UTILITIES REGULATORY POLICY \\ ACT (PURPA) AND U.S. GEOTHERMAL \\ INDUSTRY: CURRENT CONTROVERSIES \\ AND TRENDS IN FEDERAL AND \\ STATE IMPLEMENTATION}

\author{
SEPTEMBER 1988
}

PREPARed fOR:

Energy Programs Division

San Francisco OpERATIONS OfFICE

U.S. Department of ENERGy

1333 BROADWAY

OAKLAND, CaLIFORnIA 94612

Under CONTRACT No. DE-AC03-86SF16299

[MERIDIAN PROJECT No. 267]

Prepared by:

Meridian Corporation

4300 King STREet, Ste. 400

ALEXANDRIA, VIRGINIA 22302 


\section{DISCLAIMER}

This report was prepared as an account of work sponsored by an agency of the United States Government. Neither the United States Government nor any agency Thereof, nor any of their employees, makes any warranty, express or implied, or assumes any legal liability or responsibility for the accuracy, completeness, or usefulness of any information, apparatus, product, or process disclosed, or represents that its use would not infringe privately owned rights. Reference herein to any specific commercial product, process, or service by trade name, trademark, manufacturer, or otherwise does not necessarily constitute or imply its endorsement, recommendation, or favoring by the United States Government or any agency thereof. The views and opinions of authors expressed herein do not necessarily state or reflect those of the United States Government or any agency thereof. 


\section{DISCLAIMER}

Portions of this document may be illegible in electronic image products. Images are produced from the best available original document. 
TABLE OF CONTENTS

PAGE

EXECUTIVE SUMMARY.......................................

PART ONE: LEGISLATIVE AND IMPLEMENTATION BACKGROUND............... 1

1.0 INTRODUCTION................................... 1

2.0 BACKGROUND OF THE PURPA ISSUE....................... 6

2.1 PURPA: Goals and Objectives.................... 6

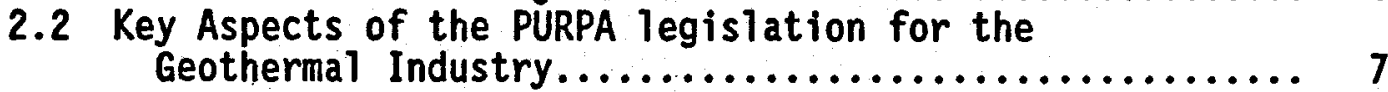

3.0 FEDERAL AND S.ATE RULE MAKING FOR PURPA IMPLEMENTATION....... 9

4.0 THE CHANGING UTILITY ENVIRONMENT FOR PURPA LEGISLATION........ 13

PART TWO: CURRENT PURPA ISSUES AND CONTROVERSIES................ 20

5.0 RECENT TRENDS IN PURPA-RELATED DECISION MAKING........... 21

5.1 Regulatory Responses to a Changing Utility Equipment..... 21

5.1.1 Local Need for Proposed QF Power............... 22

5.1.2 Lower Avoided Price Power Sales Contracts......... 23

5.1.3 Protracted Negotiations over Interconnection, Transmission and Wheeling of QF Power......... 24

5.2 Reinterpretation of PURPA for Local Public Policy

Reasons........................................ 25

5.2 .1 QF Bidding............................... 25

5.2.2 Abrogation of QF Contracts................... 28

5.2.3 Competition for Capacity by Subsidiaries of Regulated Utilities........................ 28

5.2 .4 Dispatching of QF Loads....................... 30

6.0 KEY COMPONENTS OF PURPS FOR FUTURE GEOTHERMAL DEVELOPMENT..... 31

6.1 Unregulated Status................................ 32

6.2 Guaranteed Access to Power Markets...................... 33

6.3 Avoided Cost Payments............................... 33

PART THREE: CASE STUDIES THAT ILLUMINATE KEY PURPA ISSUES FOR THE GEOTHERMAL INDUSTRY............................... 36

7.0 THE CALIFORNIA ENERGY COMMISSION VS. THE CALIFORNIA ENERGY COMPANY: REQUIRING THE DEMONSTRATION OF A LOCAL NEED FOR POWER BEFORE GRANTING DEVELOPMENT PERMITS. 
TABLE OF CONTENTS

(CONTINUED)

PAGE

8.0 SIERRA PACIFIC POWER COMPANY VS. THE GEOTHERMAL DEVELOPERS:

DETERMINING THE PORPER PRICE FOR QF POWER SALES AND

REQUIRED UTILITY COOPERATION WITH GEOTHERMAL QFS

8.1 A Brief History of the Sierra Pacific Power Company and the Power Market for Potential QFs in its Service Area. 38

8.2 The Issue of PURPA-mandated Local QF Purchases vs. Lowcost Out-of-State Power Purchases................ 39

9.0 TRANSMITTING GEOTHERMAL POWER TO MAJOR MARKETS: THE CASES

OF THE GEOTHERMAL PUBLIC POWER LINE AND THE PG\&E

AGREEMENT TO INTERCONNECT SMALL POWER PRODUCERS

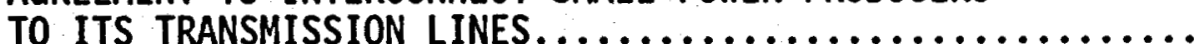

9.1 The Transmission Needs of. New Public Power Actors in

The Geysers' KGRA........................... 44

9.2 Sma11 Power Producers' Access to PG\&E Transmission Lines. 47

10.0 THE BEOWAWE GEOTHERMAL PLANT: DIRECT EQUITY PARTICIPATION BY UNREGULATED SUBSIDIARIES OF UTILITIES IN PLANT DEVELOPMENT AND OPERATION.............................. 48

PART FOUR: FINDINGS AND LESSONS FOR THE DEPARTMENT OF ENERGY AND THE GEOTHERMAL INDUSTRY.......................... 50

11.0 ASPECTS OF PURPA CENTRAL TO FUTURE GEOTHERMAL DEVELOPMENT..... 50

12.0 IMPACTS OF PURPA ON THE SIZE AND TYPE OF GEOTHERMAL INSTALLATIONS CONSTRUCTED IN THE UNITED STATES: CUSTOM DESIGNED PURPA PLANTS ........................ 53

13.0 THE CREATION OF NEW MANAGERIAL AND FINANCIAL ARRANGEMENTS TO MANAGE THE "PURPA" GEOTHERMAL POWER PLANT.

APPENDIX A: EXAMPLES OF NEH U.S. GEOTHERMAL PLANTS IN THE POST-PURPA ERA.................................... 


\section{EXECUTIVE SUMMARY}

This report is an analysis of the issues confronting U.S. energy policymakers and the U.S. geothermal industry as the result of the implementation and interpretation of the 1978 Public Utility Regulatory Policies Act, commonly known as PURPA. It seeks to answer four sets of questions about PURPA:

- What has the existence of PURPA meant to the U.S. geothermal industry?

- How has the interpretation of PURPA evolved over the past decade?

- What particular portions of PURPA rule making have been most crucial to the growth and development of the geothermal industry?

- What aspects of PURPA have been most troubling to utilities purchasing or developing geothermal energy?

PART ONE introduces background on PURPA legislation, rule setting, and the changing regulatory environment. Section 1 provides an overview of current PURPA controversies and the objectives of this paper. Sections 2 and 3 provide background on the PURPA legislation and on the all-important rule making that transformed this general law into federal and state regulations governing utility contracts. The Federal Energy Regulatory Commission's (FERC) introduction of separate capacity and energy charges is explained, along with its importance for baseload technologies such as geothermal. The introduction of pre-approved power purchase contracts, the so-called "standard offers," by key states such as California is discussed, along with its dramatic impact on geothermal projects being planned in 1983-1986. Section 4 presents the changing utility environment for the administration of PURPA, focusing on electric utility concerns that they would be forced to buy power from relatively highcost cogeneration and small power producers rather than bringing online planned baseload nuclear, coal, and natural gas-fired units. This has led to the concept of a utility "need" for power preceding 
the permitting of a PURPA qualifying facility (QF) within that utility service area.

PART TWO examines current PURPA issues and controversies. This information is based on telephone interviews with a number of geothermal developers. Section 5 presents trends and new directions in PURPA rule making in the past three years that the geothermal industry, state regulators, and utility spokesmen see as crucial. Key points of contention are: the requirement for a local need for proposed QF power; sales contracts below the "avoided cost" of power generation; and protracted negotiations over interconnection, transmission, and wheeling of QF geothermal power. Section 5 also discusses recent proposed directions in PURPA reinterpretation that cause great concern within the geothermal community because they appear to violate the original intent of the legislation. These include the bidding of QFs against one another for limited power contracts, entry of unregulated subsidiaries of regulated utilities into the $Q F$ power sales business, and utility dispatching of $Q F$ loads.

Section 6 presents the consensus views of geothermal developers on the portions of PURPA that are crucial to the continued growth and development of geothermal energy in the United States. These include: unregulated status, guaranteed access to power markets, power sales contracts based on avoided costs of power generation, long-term contracts, and guaranteed access to existing transmission facilities.

PART THREE presents four case studies that 11 lustrate key PURPA issues and controversies within the geothermal industry. These cover the range of topics presented in Part Two, but with additional information on the state rule making, utility involvement, and industry response. 
PART FOUR presents the findings and conclusions of the study. The focus primarily is on those aspects of PURPA which appear crucial to the U.S. geothermal industry, as well as the impacts of PURPA on the direction and structure of the domestic geothermal industry.

To provide more information for decision makers, a series of case studies of recent geothermal developments is included as Appendix A. 


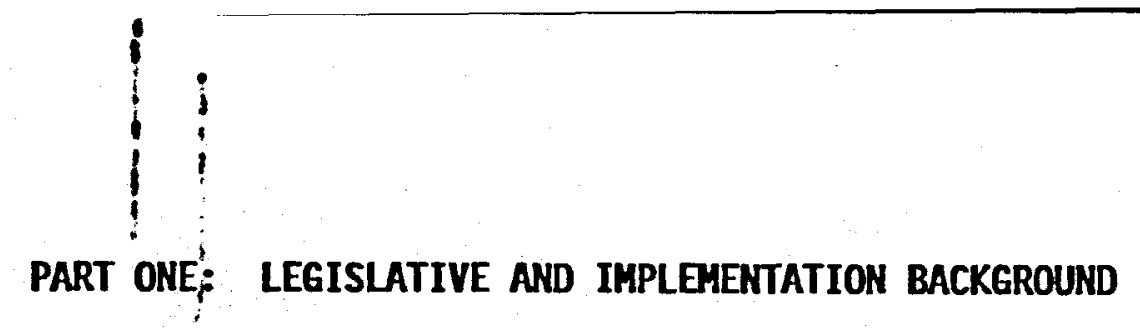

\subsection{INTRODUCTION}

In early November 1978, the 95th Congress passed the landmark Public Utility Regulatory Policies Act (PURPA) in response to the deepening national energy crisis. The legislation also reflected a widespread perception that electrical utilities were not promoting energy conservation, and were not encouraging cogenerators and smallscale entrepreneurs to produce power for the electric grid. Therefore, Congress interceded to insure that such small power producers would receive a "fair" price from their local utility, would have access to transmission lines, and would be able to negotiate long-term contracts.

It has now been nearly a decade since PURPA was signed into law, eight years since the federal implementation rules were promulgated, and approximately five years since the constitutionality of PURPA and the accompanying rule making was settled by the Supreme Court. ${ }^{1}$ The impact of this legislation has been far greater than was ever envisioned by its authors. It has drastically altered the mix of power sources for many major utilities; introduced the private developer and/or cogenerator as a major force in utility supply planning; and led to a series of unprecedecented contracting relationships among utilities, major energy-using industries, and private power developers. In California alone, between 1984 and 1986, 2,200 WWe of small (under 50 MWe) qualifying facility (QF) capacity was added to the California electrical supply system, and a

1 See American Paper Institute vs. American Electric Power, 461 U.S. 402, Supreme Court 1921 (1983) for details of the decision. 
total of 16,000 ; MWe of QF (under 80 MWe) power was under contract by utilities by the end of March 1987.2

This decade of PURPA-related power development has also been one of major change and growth for the U.S. geothermal industry. Installed geothermal capacity in the United States has increased from 608 MWe in 1978 (all dry steam plants at The Geysers) to 2,000 MWe at the end of 1987, with another 424 MWe of capacity under construction or on-line in 1988 and an additional 302 WWe in the advanced planning stages and expected to be on-line in 19893. However, there is no causal connection between the passage of PURPA and the growth of the U.S. geothermal capacity. Indeed, some industry analysts would argue that they are unrelated, since geothermal is much more of a conventional utility technology than other technologies that have benefitted greatly from PURPA rule making such as small hydro installations, wind turbines, and solar concentrators.

Since the beginning of 1986, the implementation (and indeed the very existence) of PURPA has been called into question by major electric utilities, federal energy officlals, and independent energy analysts. In public hearings, in industry trade journals, and at electrical power conferences, opponents have attacked the treatment given smal1 power producers and cogenerators since 1980 as unfair, unnecessary, and uneconomic. Whereas previous criticism of PURPA had mostly involved the questioning of the interpretations of $1 \mathrm{aw}$ contained in particular regulatory decisions, the period 1986-1987 has seen the public voicing of several much more fundamental questions:

\footnotetext{
${ }^{2}$ Cogeneration and Small Power Production: Hearings before the U.S. Federal Energy Regulatory Commission, San Francisco, CA, FERC Docket No. RM87-12-00, Statement of Michael R. Peevey, Southern California Edison Company, April 2, 1987, pp. 63-64.

3 Figures compiled from Geothermal Progress Monitor \#11, Hashington, D.C.: U.S. Department of Energy, Geothermal Technology Division, in draft.
} 
- Is PURPA any longer necessary?

- Is PURPA in the larger public interest, or does it assist the power plant developers at the expense of the ratepayer?

- Should PURPA be fundamentally redrawn to reflect the new electricity supply realities of the 1980s, rather than the scarcity concerns of the 1970s?

Accelerating this concern have been three factors: an unprecedented rise in certain states in applications for power connections from qualifying facilities (QFs) under PURPA; low fossil fuel prices, (particularly natural gas); and the increasing availability to utilities of low-cost power being sold by neighboring utilities or regional power pools. Overlaid on these concerns is the prospect that large quantities of electricity generated by hydropower may become available from the Canadian provincial utilities in British Columbia and Quebec in the near future.

This public questioning has taken place in a number of arenas, including the extensive regional hearings on PURPA held by the Federal Energy Regulatory Commission (FERC), congressional hearings, and legislative debate in key states. At the end of 1986 and early 1987, there was concern among private power developers and PURPA supporters that the law would be eliminated, watered down, or drastically revised. While this now appears unlikely to occur in the current Congress, the debate has focused unexpected attention on this 1 aw and its role in reshaping the electric power system in the United States. The debate has been far-reaching, addressing issues that are at the core of the evolution of electric power for the 1990s: the "proper" price of power today and in the next decade, the relative merits of decentralized vs. centralized power generation, the economic and financial value in minimizing imports of fossil fuels, and a score of other public policy issues.

In the issue paper that follows, we seek to provide answers to four sets of fundamental questions about PURPA: 
- What has the existence of PURPA meant to the U.S. geothermal industry and how has its terms affected the direction and growth of the U.S. geothermal industry?

- What has been the evolution of PURPA interpretation at the state and federal level over the past few years, and what problems have arisen as a result for the U.S. geothermal industry?

- What particular parts of PURPA-related rule making have been most crucial to the geothermal energy industry's growth and development?

- What aspects of PURPA have been most troubling to those electric utilities that are purchasing or developing geothermal power, and what solutions exist to minimize these problem areas?

To answer these four questions, we have used a variety of analytic and research tools. An extensive literature review was conducted to identify state regulatory trends, and to pinpoint case studies of conflicts over the interpretation of PURPA rule setting. Several sets of hearings held by FERC were examined for the official positions of key utilities, trade associations, and industry research groups. To determine the importance of PURPA to the geothermal industry, we have conducted unstructured telephone interviews with geothermal developers, utility planners in charge of geothermal operations, and staff of energy offices and public utility commissions in several key states. Each was asked to explain the role of PURPA for overall geothermal development, those aspects of PURPA that have been particularly important for the geothermal industry's growth, and how recent changes in rule making have altered this impact (if at all). Developers and utility operators were asked to describe specific cases where PURPA was important, including how plants and grid interconnections were designed to comply with or take advantage of PURPA regulations.

Because this report is focused on state regulation and on conflicts arising from legal interpretation, the attention will naturally be on the financial and contractual side of geothermal 
project development. This has been more drastically affected by the PURPA regulations than has been the basic underlying technology. However, as several authors have noted, there have been some major changes in plant design as developers have sought to optimize each system under the new rules imposed by PURPA and the state interpretations. We have tried to briefly explain the characteristics of the "PURPA" plant, with its emphasis on $100 \%$ capacity availability. This is covered in several case studies presented in Appendix $A$, which examines a number of geothermal power plants brought on-line since the passage of PURPA. 


\subsection{BACKGROUND OF THE PURPA ISSUE}

\subsection{PURPA: Goals and Objectives}

When the 95th Congress enacted the Public Utility Regulatory Policies Act (PURPA) of 1978, it sought to stimulate the development of alternative electric power systems, displace the use of imported oil and natural gas in utility power generation, and increase the geographical and technical diversity of the U.S. national electric power system. PURPA also reflected a desire to shift national emphasis from centralized, conventional nuclear and coal power plants to more decentralized installations using renewable energy systems and cogeneration.

It should be remembered, however, that small power producers and cogeneration systems were a very small part of the PURPA legislative package. ${ }^{4}$ Since Congress was preoccupied with other energy issues, Sections 201 and 210 of PURPA -- the text dealing with defining and encouraging cogeneration and small power producers -- were broadly worded. While congress voiced its intention to force utilities to "deal fairly" with small power producers by buying power from them and by transmitting their power over existing transmission lines, it provided little concrete guidance for implementation. As originally drafted by the Congress, PURPA was vague about the meaning of particular key terms and phrases that would determine the obligations of utilities under Section 210.

${ }^{4}$ Most of the attention within the text and legislative history of PURPA is devoted to the setting of new retail natural gas policies, encouraging the expansion of domestic petroleum pipelines, and altering federal energy regulatory activities. Within the electric utility area, the main emphasis was on the setting of standards for electric utilities to encourage energy conservation, make certain that each set of rates reflected the cost of providing service to that class of customers, encourage time of day and seasonal rates, require the establishment of interruptible rates, and expand utility load management activities. See U.S. Stat 3117-3173, November 9, 1978. 
This is particularly true for the "incremental cost of alternative energy" that the utility must pay a QF for power sold to the grid. Section 210 defines incremental cost as "the cost to the electric utility of the electric energy which but for the purchase from such cogenerator or small power producer, such utility would generate or purchase from another source." (P.L. 95-617, Public Utility Regulatory Policies Act of 1978, U.S. Stat 3145.) What exactly this meant was to be a matter for detailed rule making by the FERC and the individual state public utility commissions, as explained below in Section 3.0.

\subsection{Key Aspects of the PURPA Legislation for the Geothermal Industry}

When PURPA was first passed, the private U.S. geothermal industry was largely restricted to resource drilling and development firms operating within a single field, The Geysers' Known Geothermal Resource Area (KGRA). The industry developed this dry steam resource and sold the steam to a single client, Pacific Gas and Electric (PG\&E), under long-term sales contracts. U.S. geothermal energy firms, until the passage of PURPA, did not produce electricity or own power plants, since there was no requirement for PG\&E or other utilities to buy the resulting power. At the time of the passage of PURPA, the major western and southwestern utilities (serving the areas where the high-quality geothermal resources are located) saw no need for purchasing small units of power from private vendors, since the utilities themselves had ambitious baseload nuclear and/or coal plant development plans under way.

The enactment of PURPA changed all the rules. Now resource developers could become power plant operators, and the utilities were required to buy the offered power. Equally important, the utilities were required to transmit this power over existing power 1 ines to market. This point is particularly important for geothermal energy developers because the power plant must be sited at the geothermal field, which in the United States is often located in remote areas 
distant from major electricity markets. However, even the passage of PURPA did not automatically signal a new operating environment for geothermal development in the U.S. It was initially unclear what prices would be paid for the power generated.

Equally important, it was unknown what allowance would be made for geothermal energy's ability to provide primarily baseload rather than intermittent power. In two important ways, geothermal energy shares more in common with fossil fuel and hydropower plants than with other alternative technologies. First, it has very high power availability, since the resource is provided to the power plant on a constant basis. Second, the energy conversion and power generation technology for a geothermal plant is quite similar to that used in conventional fossil fuel thermal plants. Therefore, the technology used is mature, with well-known reliability factors and engineering standards. In fact, even in its developmental pre-PURPA stages, geothermal systems provided baseload plants with a higher power availability factor than nuclear and fossil-fired power facilities.

However, this reliability has a financial price to the developer. Unlike many of the other renewable energy technologies, geothermal energy requires large initial resource development expenditures, due to the high cost of the resource assessment and drilling activities. The drilling of 10 development wells in the Geysers field may cost $\$ 10$ million or more, not counting the construction of the steam gathering system, whereas there is no cost of the wind resource for a wind farm or the solar insolation for a photovoltaic array (and only modest costs for measuring their power potential). At the time of the passage of the PURPA legislation, it was not known if the high reliability of geothermal would be sufficiently rewarded to pay developers for the resource development costs. 


\subsection{FEDERAL AND STATE RULE MAKING FOR PURPA IMPLEMENTATION}

In 1979, the FERC promulgated the set of rules and guidelines required by congress for the implementation of PURPA. The resulting regulations and directives to state regulators were quite favorable to cogenerators and small power producers. FERC guidelines stated that power purchased from new QFs should receive a rate equal to the utility's full avoided cost. The FERC rule setting was very detailed, spelling out actions that should be taken for a variety of contingencies, including if the power was only available for sale to the utility on an intermittent basis. The key aspect of the FERC rulings was that the full avoided costs must be paid, with avoided costs being defined as "the incremental costs of electric energy, capacity, or both, which, but for the purchase from the QF, such utility would generate itself or purchase from another source." (18 CFR 292.101(a)(6), Emerging Policy Issues in PURPA Implementation, op cit., p 5.2).

Under PURPA, the state regulatory authorities had a year to establish the fully avoided costs of power generation for each major utility under their jurisdiction. After public hearings and notice, these rates were to become public information. The importance of this public avoided costs rate setting cannot be overestimated. Without it, many of the geothermal plants described in these pages would never have been built. With it, resource development firms, investors, and developers can estimate the potential revenue stream from a proposed geothermal installation at a given site to determine if the resource is worth developing. Alternative plant configurations can be compared, based on the common criteria of profitability.

Equally important, geothermal developers can compare alternative sites in different jurisdictions to determine the best return on investment. Before PURPA, each utility determined what it was willing to pay for steam based on an internal decision-logic. Now, 
the regulator determined what the utility must pay based on a public decision-making process. After the setting of avoided costs, geothermal developers could compare regulatory authorities and utility rates, not just the quality of the resource base. A geothermal developer could now opt to develop a mediocre brine resource in a utility service area with a high avoided cost over a top quality steam resource in a different utility service area that is required to pay a much lower cost per unit of power purchased.

Of particular importance to the geothermal industry was the FERC decision that utilities could be required to pay the QF both a capacity charge and an energy charge. Because geothermal is primarily a baseload rather than intermittent technology, its sale to the utility directly displaces capacity that the utility would otherwise have to build in the future. FERC ruled that the developer selling such reliable 24-hour power should be paid a rate which reflects this investment that the utility did not have to make. The approach of requiring both a capacity and energy charge was adopted by the California Public Utilities Commission (CPUC). The CPUC was and is the most influential of the state regulatory commissions in the creation of rules that govern utility response to PURPA-induced activities of geothermal developers in particular and renewable energy developers in general.

PURPA also led to the development of utility-wide power contracts that had been pre-approved by the state regulatory authority. These so-called "standard offers" were particularly important in California. The utilities had to agree to contracts similar to the standard offers from a QF, or face the possibility of litigation or regulatory censure (both options under PURPA). In early January 1983, the CPUC published the first three of its set of utility-specific interim standard offers, which utilities could and should use in the negotiation of power purchases from independent 
power producers or cogenerators. 5 The first three interim standard offers had only marginal importance for geothermal systems, although they were crucial for the rapid development of other renewable energy industries in California. They were:

- Standard Offer \#1: for purchases of as-available power, meaning power that was produced by intermittent technologies (such as wind turbines) or that was only avallable at certain hours of the day for sale to the utility;

- Standard Offer \#2: for purchases of power from facilities that offer firm capacity during peak periods; and

- Standard Offer \#3: for small power producers (under 100 $\mathrm{kW})$.

Standard Offer No. 4 (SO4), which was published in September 1983, was designed specifically for baseload technologies--those energy systems which would produce power round the clock for sale to the grid. Unlike intermittent technologies, baseload systems would take the place of capacity that the utility had been planning to add in the future or of power that it was buying from adjoining utilities. In these cases, the CPUC ruled that the true avoided cost of the independent power plant included a capacity charge, which is an estimate of the capital investment that the utility did not have to make from its own financial resources for this particular block of power. As of February 1, 1986, 20-year duration contracts paid from $\$ 121,000-176,000 /$ megawatt/year for firm capacity in California under Standard Offer No. 4.6 Because of the capital-intensiveness of geothermal power plants, high capacity charges were crucial to investors for the recovery of the initial plant investment. As we will see in the Mammoth Pacific and Santa Fe/Occidental case studies in Appendix $A$, the substantial potential stream of revenues from

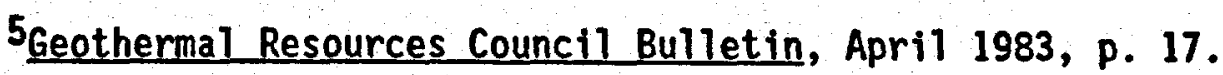

6Glenn J. McLoughlin, "Cogeneration and Small Power Development in California." Washington, D.C.: Congressional Research Service 86-782 SPR, P. 15. 
capacity charges led to additional investment in components that increased overall thermal efficiency.

Standard Offers, being pre-approved contracts at a known power selling price, may have monetary value by themselves. This is particularly true of California's initial Interim SO4 because of the long-term (30-year) fixed price capacity payments that were part of the power sales contract. Thus, when Magma Power and Magma Energy finally completed in June 1988 the sale of their interests in the B.C. McCabe Power Plant in the Imperial Valley of California, the inclusion of three $\mathrm{SO}_{4}$ contracts was crucial to the sale. One was for the 12.5 MWe McCabe binary power plant, but the other two contracts were for plants that were only in the planning stage. It is estimated that Geothermal Resources International (GEO) paid more than $\$ 1.1$ million for the Standard Offer No. 4 and drilling rights that will allow the installation of a second plant. ${ }^{7}$ With these two contracts, Geothermal Resources International will be able to go forward with the construction of two plants, each 37 MWe in capacity, under the more favorable terms of the interim S04 rather than the more stringent final S04, which was under development within the CPUC at that time.

When Oxbow Geothermal purchased leaseholdings in Nevada, one of the crucial elements of the package was the existence of a power sales contract with Southern California Edison with terms nearly identical to the interim S04. Oxbow auditors estimated that nearly two-thirds of the sales price should be attributed to the power sales contract, with only one-third assigned to the lease itself. Without the power sales contract, the lease had little practical value.

7 Geothermal Report, June 15, 1988, p. 2. 


\subsection{THE CHANGING UTILITY ENVIRONMENT FOR PURPA LEGISLATION}

From the time of the passage of PURPA, there have been questions by utllity spokesmen and consumer groups about the long-term impacts of the requirement to purchase power from Qfs. Initially, however, the need for this capacity was not a major public policy issue. Utilities were projecting large growths in demand in the following decade, and were forbidden by the Fuel Use Act from burning natural gas and oil for baseload power generation. Unexpected delays, additional regulations, and strong local opposition to the construction of nuclear and coal power plants had disrupted the utilities' capacity expansion plans. Therefore, initial utility concerns about PURPA were largely couched in terms of the management of these facilities, and their impacts on the overall reliability and integrity of the existing grid. It was assumed that there would be sufficient growth in demand to absorb the small amounts of power that QFs would produce without affecting utility expansion plans.

By the time the federal rule making was completed in the early 1980s, however, another set of primarily utility economic concerns had arisen which focused on the economic waste that PURPA could cause. Widespread industrial energy conservation, coupled with the rise of cogeneration, had eliminated much of the expected growth in electricity demand. Suddenly, utilities were concerned that they would be forced to buy power from small, relatively high-cost and inefficient systems rather than bringing on-line planned large baseload nuclear and coal units. Utility spokesmen and industry analysts warned that this would lead to a higher power cost to the consumer than would have been the case without PURPA. This fear was particularly strong in California. By the end of 1985, California utilities had signed 1,173 contracts with cogeneration or small-power producers for a staggering $15,553 \mathrm{MW}(\mathrm{e})$ of capacity. The 43 geothermal projects accounted for 1,100 MWe of this total, but this amount was dwarfed by the more than $6,700 \mathrm{NW}(e)$ of cogeneration 
projects, mostly fueled by natural gas. 8 Since most utilities are - required by the state regulators to pursue a least-cost power development strategy, there was a potential conflict between accommodating QFs and providing low-cost power to the ratepayers. In recognition of the potential or reality of higher than necessary power costs to consumers, the California Public Utilities Commission suspended the Standard Offer No. 4 on April 17, 1985, after only a year and a half of existence.

Numerous proposals have been developed by utility companies and state utility regulatory bodies in the past four years to minimize the impact of QF power purchases on the rate base. Several states, including California, decided to require the integration of utility future capacity planning with the permitting of QF applications. The basic principle is: There has to be a need for the proposed of capacity within the projected demand in the utility's service area. There is no longer any assurance that the utility will be required to accept the capacity offered by the QF. This is most pronounced in California, where every two years there is a state-wide projection of electricity demand for each utility. New cogeneration or small-power producer power offerings must fit within the projection of needed capacity. Because of the huge amount of QF power offered under the original S04, there is little or no need for additional capacity in the near future for most California utilities, and some analysts are predicting that this will continue until the end of 1990. In locations with substantial QF project activity, there has developed the concept of bidding by QFs for the power sales contract (see Section 5.2.1).

There is another concern, which has arisen in great force in utilities in the Pacific Northwest and other western power regions in the last four years, namely: firm long-term commitments to ofs for relatively expensive power under standardized contracts could prevent

8McLoughl in, op. cit, pgs. 18-21. 
utilities from purchasing inexpensive excess power being produced by power wholesalers such as the Bonneville Power Authority (BPA). The June 1988 agreement between BPA and the Los Angeles Department of Water and Power to trade capacity on the Pacific DC Intertie points to a much larger role for Northwest hydropower in California and in the Southwest. In addition, several cities which have been active in funding geothermal development through the Northern California Power Authority (see Section 9.1) have recently agreed to buy BPA power under long-term contracts. These include Modesto and Santa Clara. ${ }^{9}$ For utilities that routinely purchase substantial portions of their power, the difference in the total cost of power acquisition between local QF offers and out-of-state long-term contracts can often be substantial. As we will see in the Sierra Pacific case study below in Section 8 , the issue is now being couched in a new way: is the avoided cost of power the cost of constructing new power or of purchasing power on medium-term or long-term power from power pools and neighboring large power plants that have current excess capacity?

The two basic issues of need for power and the price for power purchased from QFs became coupled with a number of other issues by the end of 1985, leading to calls for PURPA revision or abolition. While this paper will be examining only those issues that are of prime importance to geothermal developers in 1987 and early 1988, a listing of the range of key PURPA issues may be useful for the reader at this point. Perhaps the best summary is found in a major PURPA legal review prepared in 1986 entitled Emerging Policy Issues in PURPA Implementation. The authors Identified four basic issues arising directly from Section 210 of PURPA. They are:

(1) Requirement to pay QFs full avoided costs where some lower purchase rate might provide adequate incentives for QF development and allow ratepayers to share in the benefits of lower cost generation.

${ }^{9}$ Electric Utility Week, June 20,1988 , pp. 1-2. 
(2) Requirements to pay QFs for purchases at rates in excess of full avoided cost computation, energy payments which exceed the utility's marginal energy costs, requirements for payments of capacity credits when capacity is not needed by the utility or where the power being purchased is less than 'firm,' or there is a likelihood of nonperformance by the QF.

(3) QF purchase rates which understate the utility's avoided costs including a failure to include capacity credits where capacity is deferred through purchases of QF power.

(4) Requirements to wheel power for QFs to other utilities as well as retail customers based on embedded cost differentials or where the outcome adversely affects the customers of the wheeling utility. 10

Al1 the state level actions, combined with extensive testimony by the full range of interested parties in FERC regional hearings in 1987, has triggered recent steps by federal regulators that could open the door to a basic restructuring of PURPA implementation. FERC has decided to provide overall guidance to states on PURPA-related rule making that reflects changed realities in the electric power market since PURPA was passed in 1978 and that promotes greater competition in power generation and sales. On March 16, 1988, the FERC issued three Notices of Proposed Rulemaking (NOPR), covering the areas of administrative determination of avoided costs, competitive bidding for new power generation, and regulation of independent power producers. While the proposals are quite complex and detailed, they do raise a number of issues of major consideration to private power developers in general and geothermal developers in particular.

10pfeffer, Lindsay \& Associates, Inc., Emerging Policy Issues in PURPA Implementation: An Examination of Policy Issues Related to Federal and State Efforts to Encourage Development of Cogeneration and Small Power Production under Title II of PURPA, (Washington, D.C: U.S. Department of Energy, March 1986), p. 4.8. 
Determination of Avoided Costs

FERC is proposing that the state regulatory authority must consider the utility's needs for capacity when determining avoided costs. In the event that the utility does not need capacity (as is true in the short term for several areas of California), then capacity charges should not be included in avoided cost payments. This is a very important and adverse change to baseload technologies, such as geothermal, which derive a substantial portion of their receipts from capacity payments. In addition, FERC is suggesting that avoided costs must consider potential purchases from other wholesale sources of power. This will tend to lower avoided costs rates in areas with access to low-cost federal hydroelectric power, such as Northern California, or to Canadian power available under low-cost, long-term contracts. Third, avoided cost determination should factor in the impact of the fuel used by an QF on the longterm reliability of supply. This should be advantageous for geothermal plants, which use a secure, assured fuel that is not subject to interruption, interdiction, or major price escalations.

There are a number of other changes that FERC is proposing under the avoided cost NOPR, ranging from the requirement for utilities to provide backup power to QFs to standard offers for small QFs (under 1 MW). However, two other proposed rules which do have potential implications for the geothermal industry are the right of the QF to construct and own an interconnection or transmission facility and the right of a state to permit front-loaded contracts so long as they don't exceed the total avoided cost over the life of the contract.

\section{Competitive Bidding for New Capacity}

The most important principle that FERC sought to establish in this NOPR is the legitimacy of bidding as a method for setting rates

for power purchases from QFs and small-power producers. If the state public utility authority decides to implement bidding for one or more 
of the utilities under its jurisdiction, the bidders would compete for the right to supply capacity (and energy). Moreover, all sources, including wholesale sources, must be considered in the bidding, unless there is a written rationale for any exclusion. This basic principle has little immediate impact for the geothermal industry in the western United States, since key states such as California are already encouraging bidding procedures.

However, there are a number of proposed details which may affect the geothermal industry directly. The question of whether all-source bidding includes regulated utilities outside their normal market region and unregulated subsidiaries of utilities is a matter of great concern for a number of geothermal developers. Secondly, FERC is proposing waiving the efficiency standards that have previously been imposed on oil and gas-fired cogeneration facilities, a move that may prove to be a disadvantage to geothermal systems, since this would lower still further the front-end cost of the cogeneration installations. FERC also has asked for comments on a proposal to require utilities to wheel power, a long-standing issue for geothermal developers in Northern California and Nevada.

\section{Independent Power Producers}

In its March NOPR, FERC proposed streaml ined ratemaking and relatively relaxed regulation for non-QF (i.e., larger facilities than the 80 Whe maximum allowed by PURPA) independent power producers (IPPs). The rates charged by the IPP are to be considered proper by FERC so long as they do not exceed some cost-related cap equal to or less then the utility's incremental cost of power. The price can be determined by the local Public Utility Commission (PUC), by some type of bidding process, or by direct negotiations with the utility purchasing the power. The IPP will be exempted from most of the normal utility reporting requirements for accounting and bookkeeping. 
The way the proposed regulations are worded, regulated utilities may be able to qualify as IPPs if they are selling power outside their basic service area. There is some uncertainty as to whether this utility-developed power has to be from a separate, unregulated independent power facility (IPF) subsidiary or can be power from utility-owned plants so long as it is sold outside the utility's service area. The cardinal issue for geothermal developers, as for most private power producers is: will utilities or utility-owned unregulated subsidiaries be able to sell power without regulation either inside or outside the utility's service area? Geothermal developers feel that this would be difficult to compete with, if only because of the superior financial resources of the large utility companies. There is the second concern that adjoining utilities may cooperate to shut out third-party developers. This could happen if utility $A$ agrees to buy power from the unregulated subsidiary of utility $B$, in exchange for a return agreement from $B$ to buy its next increment of power from the subsidiary of utility $A$. 


\section{PART TWO: CURRENT PURPA ISSUES AND CONTROVERSIES}

In order to determine which of the many issues raised in Part One of this report were important to geothermal energy developers in 1987, telephone interviews were held with approximately 20 individuals in May and June 1987. Follow-up telephone calls were made in June, JuTy, and August 1988 to update case study information. These individuals were concentrated in California and Nevada because of the current high level of regulatory attention and of QF geothermal applications in those two states. While over half of the sample contacted were geothermal developers, an effort was made to discuss these same issues with state regulators and utility representatives from these same states.

These open-end interviews were focused on two sets of issues. First, geothermal developers were asked to discuss their experience with recent interpretations of PURPA by state regulators and electric utilities, and provide their observations of the current climate and how it will affect projects under negotiation and future planned projects. State regulatory staff and utility contract specialists were asked to comment on the same areas, but with emphasis on what issues they saw as currently of central importance for QF negotiations in general and geothermal negotiations in particular.

Second, geothermal developers were asked to discuss what portions of the package of PURPA-related rights and obligations they saw as crucial to the continued expansion of the geothermal industry. If changes were to be made to the underlying legislation or if FERC guidance were to change, what would they see as central to the continued role of geothermal QFs in the provision of power for utilities. 


\subsection{RECENT TRENDS IN PURPA-RELATED DECISION MAKING}

There is a broad consensus among geothermal developers, state utility regulatory staff, and utility spokesmen that the direction and intent of PURPA are being drastically revised by state regulatory decisions made in the past three years. Although FERC and the Congress debated changing the law, several key states have in fact changed its impact on cogenerators and small power producers through their interpretations of key components of the act. These changes fall into two different categories, each with very different implications for the long-term viability of geothermal development: Regulatory responses to the changing utility environment, and reinterpretations of PURPA for local public policy reasons.

\subsection{Regulatory Responses to a Changing Utility Environment}

A number of individuals interviewed noted that PURPA was passed during a period of rapidly rising fuel prices, unexpected delays in baseload power plant construction, rapidly rising power consumption, and projections of massive power capacity shortages. The utility environment in 1988 is almost a 180 degree reversal of this: low prices for all fossil fuel forms, slow growth in electrical demand, and widespread excess power production capacity. State regulatory authorities have responded to this new environment, since they deal with issues and requests on a case-by-case basis. While a number of these rulings have not been particularly favorable to geothermal development, industry spokesmen see them as logical and reasonable judgments. The expectation is that these decisions are reversible, once the current temporary surpluses of power generation capacity and QF applications are gone, and once fossil fuel prices begin to rise again. There are three basic issues which fall into this category of responses to the changed environment. 


\subsubsection{Local Need for Proposed QF power}

In the original PURPA legislation, there was no mention made of markets for power. It was assumed that utilities would be able to make room for this new privately generated power by simply slowing their pace of power plant construction. Since 1986, however, certain utilities have been predicting that they will not need to construct any new capacity in the foreseeable future due primarily to the arrival of large blocks of cogenerated power. Additional increments of QF power would only increase potential surpluses. In response, some state utility commissions are now requiring that QFs demonstrate that there is a need for the power that they are proposing. This process is most advanced in California. There each utility prepares a resource plan to determine what avoidable resource plants exist, and the state in turn develops a 30 -year projection of energy needs by utility service area. In California, a QF must receive a state permit demonstrating that it has met all the myriad environmental and siting regulations, and that there is a need for the power. By taking this approach, the state is mandating that utility capacity planning be integrated into the PURPA QF permitting process. The state has refused permits to several geothermal developers, even though they qualify as PURPA QFs, on the grounds that they cannot demonstrate that the local utility or private users require this power. Granting such permits, the state argues, only increases the local surplus of power, and displaces low-cost baseload coal and nuclear power.

Geothermal and other QF developers have argued in state regulatory proceedings that the need for power is not considered by the original PURPA legislation, and that not requiring the utility to purchase offered QF power is counter to the intent of PURPA. Privately, most of the geothermal developers say that they understand the regulation, which was brought about (in the case of California) in part by the avalanche of $\mathrm{QF}$ applications under the attractive standard offers. Many of the initial QF applications under the 
Interim SO4 were speculative and will never be exercised, so the expected glut of QF power is illusory and transitory. Within a few years, legitimate Qf developers will be able to demonstrate a need for power again and the problem will be solved.

\subsubsection{Lower Avoided Price Power Sales Contracts}

Prices being paid for new QF power are dropping. Some portion of this drop is due to recent decreases in long-term fossil fuel costs, which in turn have lowered utilities' avoided costs. The coming on-line of several large nuclear plants has also lowered the avoided cost of several key West coast utilities. But, far more important, the value of capacity created by QFs is worth less in a period of excess capacity. If a utility needs only small amounts of firm power for the next decade, then it may not need to pay substantial capacity payments to QF power provided now. Standard offers for long-term baseload power have been revised downward in recent California decisions, and a 1987 decision in Nevada dropped the long-term avoided cost rate in northern Nevada from 6.3 to 5.55 cents/kWh. In some states, avoided-cost rates in 1988 are only $50 \%$ of what they were three to four years ago.

It is now more difficult for potential QFs bargaining with utilities to win contract terms which will be attractive to thirdparty financiers, whereas three or four years ago the long-term contracts were sufficient or even lavish. The dropping of long-term contract prices being received by new QFs is being accelerated by the arrival of bidding for power contracts, which pits geothermal developers against one another and against cogenerators, wind developers, and other potential sources of QF power (see Section 5.2.1). 
5.1.3 Protracted Negotiations over Interconnection, Transmission and Wheeling of QF Power

Utility spokesmen and geothermal developers both agree that they are often in an adversarial relationship, and that this confrontation changes most strongly in areas that appear to be strictly power system engineering questions: interconnection protocols, interconnection equipment, QF transmission routing, and utility requirements and charges for wheeling of power to third parties. QFs want to gain this market access with a minimum cost and a minimum delay. The utility wants the QF to conform to its planning process, and is relatively unconcerned about the speed of the negotiation process. The utility engineer seeks to protect the overall power system from any damage or disturbance that the QF might introduce. The utility does not want to incur any expenses from the addition of QF power to its grid, and wants to protect its current or planned investment in generation as well as transmission and distribution equipment.

While this opposition of interests is to be expected, transmission and wheeling of power from geothermal plants has turned out to be a problem that is limiting project development in many potentially attractive areas. 11 In some cases, the geothermal resource is located far from transmission lines, and the issues then become: who pays for the development of the line, and is the line itself part of the unregulated QF or part of the utility's system? When Oxbow Geothermal wanted to develop its site at Dixie Valley, Nevada, it was more than 60 miles from the nearest transmission substation. Oxbow chose to build itself a 214-mile-long $11 \mathrm{kVa}$ transmission line directly to Bishop, California, in order to take

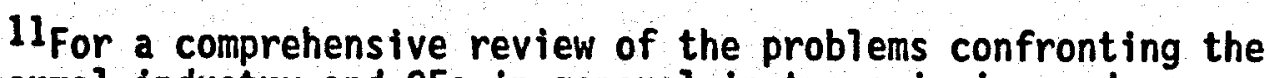
geothermal industry and QFs in general in transmission and interconnection, see George M, Knapp, "Transmission Access and Interconnection, " Geothermal Resources Council Bullet in, January 1987, pp. 11-14. 
advantage of the power purchase contract from Southern California Edison it had bought with the geothermal lease. In a landmark decision on May 19, 1988, FERC ruled (Docket No. QF84-256) that the transmission line was to be considered part of Oxbow's qualifying facility under PURPA, and not subject to Federal Power Act regutations. 12

The major recurrent transmission problem, however, is that many proposed geothermal plants are served by power lines that are heavily loaded. The existing transmission system will not be able to handle the new capacity when it comes on-line. This is 1 imiting geothermal development particularly in the Imperial valley in Southern California, since the power produced by the rapidiy expanding geothermal capacity must be transmitted over the limited lines of the local irrigation district. The solution appears to be to build new or parallel lines; but who is to pay for them? In several areas, the developers have banded together to get dedicated transmission lines constructed, as discussed in the case study below.

\subsection{Reinterpretation of PURPA for Local Public Policy Reasons}

It is of great concern to the geothermal industry when a local utility or state regulatory body proposes or passes rules which seem to violate the intent and spirit of the original PURPA legislation. Four primary issues were raised in discussions: QF bidding, abrogation of QF contracts, utility unregulated subsidiaries, and dispatching of QF loads. Each will be discussed separately in the sections that follow.

\subsubsection{QF Bidding}

In several locations with excellent geothermal resources, the limited projected demand for additional capacity, often coupled with

${ }^{12}$ Electric Utility Week, June 27, 1988. 
substantial cogeneration potential or high-quality non-geothermal local energy resources, has indicated to regulatory and utility planners a potential surplus of QF power. This has led to a most intriguing (and most disturbing for the geothermal industry) development: the emergence of of bidding. The concept is simple: the state regulatory agency allows or requires local utilities to solicit bids from cogenerators or small power producers to provide a certain amount of required future generating capacity. While issues such as reliability of power and guaranteed power availability are important, the major component of each bid is what price the QF will charge the utility for the power to be sold. This leads to substantial discounting from the utility's avoided cost figure by many bidders. Since utilities tend to accept offers from the low bidders until the required block of capacity is provided, this system leads to a lower cost of power for the utility's customers.

The concept of bidding has been formally or informally incorporated in the procedures of many state regulatory bodies in the past two years. It was a main topic of discussion in the regional FERC hearings held in the spring of 1987. On May 29, 1987, the California Public Utilities Commission, in Decision 87-05-060, which set up Final Standard Offer No. 4 terms, reaffirmed its 1986 decision to allow QFs to compete directly for providing the power needed by a utility over the first eight years of its 20 -year research plan. To compete, the QFs must submit sealed bids stating the minimum price at which they will offer electricity. If bids by QFs are greater than the power capacity required, then the lowest bidding QFs are to receive the first contracts. 13 On June 10, 1987, the chairman of FERC went on record as favoring competitive bidding for electric

13 Geothermal Report, July 1, 1987, p. 3. Also see William B. Marcus, Jeff A. Nakigian, and Gayhatri M. Schilberg, Regulatory Cases Will Determine Future Cal ifornia QF Market, Alternative Sources of Energy/95, (November 1987), pp. 8-12. 
power supply whenever it is feasible. 14 By May of 1988, competitive bidding systems for QF projects were in place or under development in seven states and being considered in 15 others. 15

QF bidding is seen as a serious threat by some geothermal energy developers. In areas where there is an abundance of low-cost natural gas, large (50-500 MWe) gas-fired cogeneration plants are being built at a dizzying rate. The low capital and resource development costs of these gas-fired systems makes their break-even cost much lower than that of even the most efficient geothermal plants. Therefore, whenever there is a bidding process, these cogenerators have been winning most of the available capacity contracts, shutting out the more expensive baseload geothermal energy projects, even though geothermal projects are economically viable at power sales prices equal to or slightly below the utility's avoided cost.

Geothermal developers interviewed have three basic objections to QF bidding. First, it encourages unrealistically low bids by inexperienced groups, which shut out the more experienced or prudent developers.

Second, mixed competitive bidding (a11 QFs, regardless of energy source bidding for the same block of capacity) favors installations that burn fossil fuels, because of their low front-end capital cost, rapid development time, and access to low-cost fuel today. There is a strong feeling that PURPA was designed specifically to reduce, not increase utility dependence on $0 i 1$ and natural gas for power generation. In a few years, state regulators may suddenly be faced, as they were in the mid-1970s, with requests to pass through to consumers rapidly rising fuel prices (this time the request coming from cogenerators). Several geothermal developers suggested that the bidding be restricted to competition among representatives of a

14 Wind Energy Weekly, vol. 6, no. 259, June 18, 1987, pp. 2-4. 15 Electric Utility Week, May 16, 1988. 
single technology or similar units for a particular block of capacity.

Third, bidding is moving away from the basic concept of PURPA -- the utility must pay to QFs and small power generators the fully avoided cost of power generation. Bidding implies that the concept of the price of locally available power purchases is the proper cost comparison. This is attractive to utilities and consumers because it is currently much lower than avoided cost, but it does not affect the long-term systemic cost of privately generated power.

\subsubsection{Abrogation of QF Contracts}

In early 1987, several 1arge utilities (led by Pacific Gas and Electric of California) charged that they were being forced by state procedures to pay too much for QF power that they did not want or need. The estimates of these alleged over-payments were very large, up to $\$ 3$ billion in the case of PG\&E, and disturbing to legislators and consumer advocates. Legislation was introduced in California in 1987 to allow utilities to break contracts with QFs if they felt the power was too costly or if they could demonstrate it was not needed. The legislation was never reported out of committee or acted upon but it had a chilling effect nonetheless. While the issue is currently not a highest priority among QF leaders, they are still concerned that California and Nevada utilities will want to take advantage of low-cost power from other sources (such as from the Pacific Northwest), and will press to break QF contracts to allow them to purchase large blocks of power from outside their service areas.

\subsubsection{Competition for Capacity by Subsidiaries of Regulated Utilities}

In the initial rule making for PURPA, utilities were excluded from competing with QFs for sales of power within their service 
districts. They could have up to $50 \%$ ownership of power plants outside their own service areas, unless excluded by state regulatory authorities. Within the past two and a half years, there has been a great deal of discussion at the state and federal regulatory level of allowing separate unregulated subsidiaries of utilities to compete with QFs for available blocks of power. This has affected geothermal as well as fossil fuel developers. There have been several instances since mid-1985 where a utility subsidiary has participated as an equity partner in which a PURPA geothermal project has been located outside its own service area, with the resulting power being wheeled to the parent utility or sold to another utility. Arrangements at one such plant, the Beowawe Geothermal Plant, are briefly outlined in Section 11. In another recent case, the California Energy Company announced in September 1987, its intention to team with Mission Power Engineering Company, an unregulated subsidiary of Southern California Edison, and with Credit Suisse to build as many as 10 geothermal plants at the Coso project at China Lake, California. 16 By mid-March 1988, California Energy was able to announce the start-up of two additional 27.2 MWe geothermal plants, with Mission Power Engineering providing the $\$ 70$ million system on a turn-key basis. By December 1989, California Energy expects to have a 230 MWe capacity geothermal complex completed and operating. 17

Several geothermal developers expressed concern that the existing independent power industry would be destroyed, if forced to compete directly with the superior financial resources of unregulated subsidiaries of regulated electric utilities. Visions have been invoked of utilities only granting power capacity contracts to other utility subsidiaries, in exchange for similar treatment in the service areas of these same utilities. This concern has been heightened by statements by FERC chairman Martha Hesse before the

${ }^{16}$ Geothermal Report, October 15, 1987, p. 2.

17 Geothermal Resources Council Bulletin, May 1988, p. 20. 
Edison Electric Institute, where she said that FERC was considering allowing utilities to own $100 \%$ of a private power project outside their service areas, but that this would require a change in the underlying legislation. 18

\subsubsection{Dispatching of QF Loads}

For the past three years, a number of utilities have voiced the concept that they should have the right to take QFs on- and off-line, just as they do with their own power plants, to match loads and to ensure the consumers are being provided with the lowest cost power at any given time. 19 In typical utility dispatching of its own generation, the most expensive power is shut off first as load decreases, and then each generating facility is shut down in descending order of power generation cost until the generation is matched to the demand. Currently, utilities are required to buy power from QFs whenever it is offered, even if it is a period of low. demand. Utilities have maintained that high-cost QF power has become such a significant fraction of power generation that they are being forced to shut back baseload nuclear, hydro, and coal-fired plants in low demand periods, raising the cost of electricity and violating the requirement from the public utility commission to follow a least-cost operational strategy.

Geothermal developers feel that dispatching is particularly harmful to geothermal plants. It is very difficult to reduce the power output of a geothermal plant on a short-term basis, since the power generation system is designed to use a constant amount of steam or brine resource per hour and not to fluctuate. In addition,

18 Wind Energy Weekly, vol. 6, no. 259, June 18, 1987, p. 3.

$1{ }^{19}$ For a discussion of the logic of QF dispatching from a major utility perspective, see Sebastian J. Nola and Alan R. Schapiro, "Dispatching Cogeneration to Meet Electric System Operating Requirements," in EPRI Geothermal Conference and Workshop (Palo Alto: Electric Power Research Institute, June 1987). 
dispatchability would eliminate the developer's ability to predict the revenue flow for the installation, since that would totally be a function of utility controls.

\subsection{KEY COMPONENTS OF PURPA FOR FUTURE GEOTHERMAL DEVELOPMENT}

Most geothermal developers are realistic businessmen. They realize that the environment for non-utility power generation has changed, in part due to public perceptions that QF power is costly, inefficient, and unneeded in the current period of excess utility power generation. They expect this changing public perception to be reflected in state regulation or even in the underlying federal statutes. They expect increased emphasis on capacity planning as a part of QF permits, as well as increased popularity for concepts such as QF bidding.

They are also generally optimistic that this period will pass in the next two to three years. Most expect that much of the thousands of megawatts of QF power slated for development, particularly in California under the old interim S04, will never be installed. Geothermal developers are particularly skeptical that many of the large wind farm proposals, as well as some of the large biomass combustion and industrial cogeneration projects, will ever receive state permits or find the financing required to move the projects to the construction stage.

In addition, some of the utility projections for power availability from coal and nuclear power plants are seen as exceedingly inflated. Once this is realized by the state regulatory agencies, geothermal developers feel that there will be a revision in the state power supply projections, which will result in the need for more additional firm baseload power from technologies such as geothermal energy. 
Geothermal developers were asked to select what components of PURPA were most important to their continued operations. There was a consensus on five crucial components of PURPA for geothermal QFs: Unregulated status, guaranteed access to power markets, avoided cost payments, long-term contracts, and guaranteed access to existing transmission facilities. Once one moves beyond these five key PURPA guarantees, there is little unanimity. In fact, there is a scattering of opinion on what other portions of the original legislation are necessary for the industry's growth and maturation, and these are normally based on the developer's experience with a particular utility or with a particular public utility commission.

\subsection{Unregulated Status}

Geothermal developers interviewed feel very strongly that unregulated status is essential to their success. Because the rates of return on investment that they can earn are not governed by state authorities but by the business environment, they can take greater risks and accommodate more uncertainty than a utility. The higher rates of return afforded by an regulated status also are necessary to attract third-party financing for resource development and power plant construction. Second, they are exempt from much of the reporting procedures with which regulated utilities must comply. While this may appear to an outside observer to be a minor issue, several developers said that they would have to go out of business if they had to hire the staff required to provide reporting to state and federal regulators. For example, the Florida Public Service Commission has ruled that it has jurisdiction in cogeneration or small-power projects where there is third-party financing involved. 20 While this has little impact on the geothermal industry, such actions do have the potential for a major impact on the independent power industry as a whole. Third, geothermal developers are not restricted

\section{0"PSC Chills Prospects in Florida," Alternative Sources of} Energy, 195, (November, 1987), p. 10. 
to a particular service area, but can search out good opportunities wherever they exist. This considerable freedom is essential to continued resource development and to the search for new markets.

\subsection{Guaranteed Access to Power Markets}

PURPA requires that utilities must bargain in good faith with qualifying facilities for power purchases. While this process is mediated by the state regulatory bodies, private power operators nevertheless have the option to sue utilities that refuse to provide that market access. Since utilities in most areas have a monopoly on the distribution and transmission of electric power to all consumers, this access is seen by all involved in geothermal development, be they utility managers, developers, or customers, as central to the establishment of a private power industry in the U.S. This guaranteed access is perhaps even more crucial for geothermal energy than for most other renewable energy sources because geothermal fields are often located far from centers of population and industry. There is little opportunity for direct power and steam sales to large-scale industrial users, as a number of cogenerators have done successfully. The investment to create new power transmission lines to distant major population centers would often be prohibitive for smaller geothermal projects, so the access to existing power lines is a necessity for cost-effective development.

\subsection{Avoided Cost Payments}

All of the geothermal developers interviewed and most of the state regulatory staffs feel that the initial FERC decision that PURPA's legislative intent was to include the payment of fully avoided costs has been and remains crucial to geothermal development in the U.S. Without the concept of long-term power sales contracts based on predetermined avoided cost payments, developers would not be able to raise the funds for capital-intensive drilling and plant construction. For most of the western states, including California, 
Utah, and Nevada, fully avoided costs are taken to mean the cost of planning, constructing, operating, and fueling a large baseload "proxy" coal-fired power plant or, more rarely, a natural gas combined cycle plant. In practice, it is the capacity payment for every kilowatt of delivered power over the life of the power plant that makes the financing of geothermal field development and plant construction possible.

Several developers argued that full avoided cost payments were necessary, even in the current period of surplus power generating capacity, because of the risk that the geothermal developer takes. Until several developmental wells are completed, at a cost of several million dollars, the quality of the resource and its economic viability are unknown. The developer is taking a risk that the utility would otherwise have to take and should be repaid for this risk.

In the current regulatory environment, with its emphasis on stimulating competition among potential Qf firms for the right to sell power to the grid, geothermal developers recognize that fully avoided cost is becoming the upper ceiling for power sales rather than the norm. Utilities are demanding, and many are winning, substantial discounts from this benchmark price. To be competitive with cogeneration systems, geothermal developers have been forced to lower their power sales price below that allowable under PURPA.

Utility firm contract specialists and legal counsel have a very different view of the necessity and wisdom of using proxy plant data for avoided cost calculations. In 1987 presentations before FERC and state regulatory proceedings, several large utilities heavily involved with geothermal development proposed that QFs receive only some set fraction of the fully avoided cost, that capacity payments be made only when the QF can prove that a specific utility power 
plant is being avoided, and that bidding or auction systems be introduced in place of avoided cost criteria. ${ }^{21}$

Utility firms are particularly sensitive to what are commonly termed "PURPA machines." These are generally natural gas-fired plants that are nominally cogenerators, but in fact are plants that are operated almost exclusively for the production of power during peak periods, when the utility is forced to pay the highest PURPA rates for power. These are really peaking plants, which are privately owned and operated. While geothermal facilities are almost exclusively baseload plants with little ability to increase output during peak periods, geothermal developers are experiencing some of the opposition being directed at the large natural gas-fired cogeneration plants.

${ }^{21}$ Cogeneration and Small Power Production: Hearings before the U.S. Federal Energy Regulatory Commission, San Francisco, CA. FERC Docket No. RM87-12-00, Apri1 2, 1987. See the testimony of Michael R. Peevey, Southern California Edison Company and Howard Golub, Pacific Gas and Electric Company, pp. 63-80. 
PART THREE: CASE STUDIES THAT ILLUMINATE KEY PURPA ISSUES

FOR THE GEOTHERMAL INDUSTRY

\subsection{THE CALIFORNIA ENERGY COMMISSION VS. THE CALIFORNIA ENERGY COMPANY: REQUIRING THE DEMONSTRATION OF A LOCAL NEED FOR POWER BEFORE GRANTING DEYELOPMENT PERMITS}

In its biennial appraisal of state power demand and supply, the California Energy Commission (CEC) provides projections of the need for power generation for each of the major California utilities, along with its best estimate of the expected sources for that capacity (cogeneration plants, geothermal plants, utility-owned power fossil fuel plants, etc.). This "need for energy" estimate serves as a guideline for the CEC staff as they evaluate proposals from developers or utilities seeking a state permit for power plant operation. As the number of pre-approved QFs has increased in the past three years, the "need" for new power generation in many California locations has dropped dramatically or even disappeared. Now developers find that having access to a high quality geothermal resource and secured financing is not enough if there is not nearby need for the power being proposed.

The California Energy Company, a San Francisco-based geothermal development firm, has recently had to dispute this very issue with the CEC. The California Energy Company has both surface and subsurface rights and leases from the Navy and the Bureau of Land Management (BLM) to geothermal resources on the China Lake Naval Weapons facility, which is within the Coso Hot Springs KGRA. In addition to the required federal leases, in 1984 and 1985 the firm acquired three SO4 contracts, which gave it the right to sell up to 240 MWe of power on a long-term basis to Southern California Edison at a highly favorable rate.

Since 1984, the California Energy Company has undertaken considerable geothermal exploratory work within the China Lake Naval 
Reservation, and has determined that the resource is both large and high quality, able to support more than 240 MWe of generation over a 30-40 year period. During the period of initial project design, the California Energy Company staff did meet with the California Energy Commission to make certain that the project, being located within a naval facility and only having a planned first unit of 30 MWe, was exempted from the CEC permitting process.

In 1987, after completing the environmental permitting process, the California Energy Company proceeded to design and install the first 30-MWe module of the first 80-MWe power plant. At that time, the CEC staff asked for additional information about the current and planned plant, and raised the issue of whether it should be covered by the CEC permitting process. For the developer, the major concern was the issue of "need for power." While the utility has agreed to buy the power generated, this does not mean that, from the state's perspective, this increment of power is needed. The developer became very concerned that CEC intervention would mean a delay of a year or more, as well as destablization of its lenders.

In the spring of 1987, the legal staff of the developers, the BLM, the Navy, and the Southern California Edison Company met with the CEC staff to discuss these issues. While the initial focus was on whether the commission has jurisdiction in this case, the larger issue was whether or not under PURPA QFs have to prove that the power they produce falls within a projection for future demand derived from utility and state demand and supply projections. After lengthy discussions, all parties agreed to allow the plant construction to continue, and Unit 1 went on- 1 ine in July 1987. Since that time, construction has begun on Units 2-5, and all are projected to be operational by the end of 1988.22 2-3.

22Geothermal Report, Volume XVII, No. 6 (August 15, 1988), pp. 
8.0 SIERRA PACIFIC POWER COMPANY VS. THE GEOTHERMAL DEVELOPERS: DETERHINING THE PROPER PRICE FOR QF POWER SALES AND REQUIRED UTILITY COOPERATION WITH GEOTHERMAL QFS

\subsection{A Brief History of the Sierra Pacific Power Company and the Power Market for Potential QFs in its Service Area}

Sierra Pacific Power Company (SPPCO) is a small utility serving customers in northern Nevada, mainly in the Reno area, with an estimated peak demand in 1987 of 765 WWe. It derives 250 MWe of capacity from its helf ownership in the Valmy 1 and 2 coal-fired power plants. It also is located in an area with extensive geothermal resources, which have been actively explored in the past five years by a number of major petroleum company geothermal subsidiaries and by independent developers.

After a period of unfruitful negotiations with several geothermal resource companies on joint resource development, SPPCo entered into three "R\&D" contracts with geothermal developers. Under the terms of these contracts, SPPCo agreed to pay a levelized price of approximately 6.5 cents/kWh for the first 15 years of plant operation. This was above the avoided cost rate of 5 cents/kWh that the utility used for its internal planning and for PURPA-related power purchase negotiations, and was designed to stimulate geothermal applied R\&D and commercialization in Nevada. As result of these R\&D contracts, plants of 10 MWe (Beowawe), 9 MWe (Desert Peak), and 5 MWe capacity (Steamboat Springs) were installed by the end of 1986.23

QF producers within the Sierra Pacific service area in northern Nevada are confronted with an unusual problem: they have no access to Las Vegas, the major power market in the state. The SPPCo

23Washington State Energy Office and Oregon Department of Energy, PURPA Influence on Contemporary Geothermal Plants: Case Studies 1986. Prepared for the Bonneville Power Administration, DOE/BP-13609-4, February 1987 unpublished draft, Appendix I. 
transmission system is not linked with that the Nevada Power Company, but rather is linked to out-of-state utilities in Idaho and California. This means that SPPCo is the only market for a northern Nevada QF wanting to take advantage of Nevada Public Service Commission-mandated power purchase prices. This is made more troublesome by SPPCo's expressed disinterest in QF purchases, as will be explained below.

\subsection{The Issue of PURPA-mandated Local OF Purchases vs. Low-cost Out- of-State Power Purchases}

The Sierra Pacific Power Company and the Nevada Public Service Commission (PSC) have had a running dialogue over the correct future power development strategy for northern Nevada. The role of geothermal power and other QF power was a major topic of conversation and controversy throughout 1985 and early 1986, with the utility arguing for a large role for coal-fired power in the late 1980s and early 1990s. On June 26, 1986 (Docket No. 85-1005), the Nevada PSC issued interim standard offers for QF purchases for 15-, 20-, and 30year contracts. Based on a proxy coal plant model, the 30 -year contract used a power purchase price of about 6.3 cents $/ \mathrm{kWh}$. This was to be effective for one year, and then was revised based on public hearings and additional study by the PSC staff. SPPCo asked for a rehearing, on the grounds that this rate was excessive and far above the price of power purchased from out-of-state utilities on long-term contracts.

On December 5, 1986, the Nevada PSC rejected major portions of SPPCo's 20-year resource plan, which was built largely on the construction of Nevada-based coal plants and the purchase of power wheeled from neighboring states. The PSC said that QFs should be given first priority, and that the 38 MWe of new capacity that the 
utility had projected for the period through 1988 should be provided by local QF power sources. 24

SPPCo protested both the QF long-term rate and the PSC decision to grant priority to QF producers over the utility's own plans for power purchases. It launched a public relations campaign, including mass mailings to its customers about the QF ruling, which warned that:

"This 6.3 cents per kWh price is:

- Higher than the price of abundant low-cost electricity SPPCO. can buy from the Pacific Northwest.

- Higher than SPPCo's cost to generate electricity in its own coal-fired plants.

Because of having to purchase this 35 MW of higher-priced QF electricity at 6.3 cents per KWh, SPPCo customers will have to pay $\$ 7$ million more annually in future electric rates...vs... the cost of the same amount of electricity from other lower-cost sources." 25

Throughout the last half of 1986 and early 1987, three activities went on in parallel:

- hearings before the PSC on QF avoided cost calculations,

- discussions of transmission and wheeling difficulties in and between the northern and southern Nevada grids, and

- negotiations between numerous geothermal developers and Sierra Pacific over interconnection issues preliminary to signing of power contracts under the announced June 1986 rates.

24Geothermal Resources Counctl Bullet in February 1987, pp. 18-19. 25 Sierra Pacific Power Company brochure, [no date]. 
Much of the attention was focused on the "proper" avoided cost for QF power. SPPCo proposed that the avoided cost be based on a long-term power contract with Pacific Power and Light, which would sell baseload power from its 1300 MWe coal-fired plant in Montana. The pricing for electricity would start at 2.2 cents/kWh in 1987 , increase to 5.3 cents in 1993, and then increase after that date based on a predetermined formula. Local geothermal developers argued that it should be based on a proxy coal plant that would be built in the future, rather than on power purchased from an existing plant, and that this would produce a 30-year contract, based on a 1988 year of need, starting at 5.67 cents/kWh. In July of 1987 , the Nevada PSC announced its new standard offer contract decision for northern Nevada (the SPPCo service area). It accepted the concept of a proxy in-state coal-fired power plant, and determined that the avoided cost rate for long-term contracts should be 5.55 cents $/ \mathrm{kWh}$.

Simultaneously, many of the QFs were finding it expensive and difficult to work with SPPCo for the planning of interconnections and transmission for proposed installations. All of the QFs were trying to get a system installed and operating within a year of the PSC rate ruling date of June 26, 1986, so that they could qualify for the 6.3 cents/kWh rate. They felt that the utility moved exceedingly slowly on their requests for interconnection studies. There was and is a pervasive feeling that the utility was simply not interested in cooperating with the QFs in any of the required advanced planning. In addition, several of the smaller QF developers felt that the system protection the utility demanded was excessive. For any installations over 1 MWe, the utility required remote control equipment, including radio or telephone communications with the SPPCO control room to allow the utility to remotely take the QF off-line. Such a system can cost from $\$ 30,000$ to $\$ 200,000$, and typically runs from $\$ 50,000$ to $\$ 100,000$.

As the spring of 1987 passed, only one geothermal installation had qualified for the new PSC rates, and this was a small (0.8 MWe) 
binary plant at Wabuska which had already been in operation. Several developers filed a formal complaint with the PSC that the utility was not negotiating in good faith, and asked that the long-term rates proposed on June 26,1986 be extended until the negotiations were completed. The geothermal developers were not successful in this effort. The PSC ruled in favor of Sierra Pacific, since they felt that the developers had not proved that the utility was acting in bad faith. Several of the deadlines facing developers were extended, on a case-by-case basis, but the whole process was not altered.

However, the confrontation between the geothermal developers and Sierra Pacific still has not abated a year later. On April 15, 1988, Sierra Pacific issued a solicitation for bids for new power supply options. The local geothermal industry felt that this was another way to try to get around having to purchase QF power, and that this solicitation both violated the avoided cost rulings of the PSC and the utility's own resource $p l a n$, which is required as part of the state's long-term capacity planning process. In the late summer and fall of 1987, the Nevada PSC had considered Sierra Pacific's proposal for a bidding process for power purchases. While interested in the concept, they had decided not to allow bidding until more information could be gathered and the legitimacy of bidding under PURPA could be explored. When Sierra Pacific went out for bids, it was seeking prices lower than the long-term QF schedule that the PSC had established in July of 1987 . It was also saying that it needed to purchase more power than was stated in its resource plan (which had all been set aside by the PSC for QF purchases). The Nevada Geothermal Industry Council protested, and sought an immediate cease and desist order from the PSC. While the Council was not successful in this, the PSC did issue an order, barring Sierra Pacific from signing any contracts based on the Apri1 solicitation until hearings could be heard. The second concurrent issue, which was whether Sierra Pacific was abrogating its own resource $p l a n$, still remains to be resolved as of July 1988. 
Sierra Pacific argues that the QF industry is overreacting and that the ground rules have now changed. In General Order No. 32, amended in January 1988, the PSC has agreed that utilities and QFs could agree on alternative contracting procedures, which could include alternate rate structures other than the QF avoided cost. The utility clearly feels that the proposed solicitation falls under the coverage of this order.

All the controversy has not meant, however, that the geothermal industry has not been able to press ahead with development in Nevada and that accommodations have not been reached with Sierra Pacific. As of March 1988, 39.8 Mhle of capacity had been installed by developers within Sierra Pacific service area. Another 16 MWe has been developed at Beowawe that is being sold to Southern California Edison, and the Dixie Valley project being completed by 0xbow in mid1988 will ship another 60 MWe of capacity to Southern California Edison. 26

\subsection{TRANSMITTING GEOTHERMAL POWER TO MAJOR MARKETS: THE CASES OF THE GEOTHERMAL PUBLIC POWER LINE AND THE PG\&E AGREEMENT TO INTERCONNECT SMALL POWER PRODUCERS TO ITS TRANSMISSION LINES}

When geothermal power was originally developed in northern California, it was primarily under the direction of the Pacific Gas and Electric Company (PG\&E), which purchased steam from private resource firms, erected power plants in the Geysers KGRA, and developed 1,125 MWe of generating capacity for the use of its northern California customers in the period 1960 to 1983 . The creation of transmission capacity for this geothermal power was directly coupled to the utility's creation of generating capacity, and was a normal part of the utility planning process.

26 For a listing of the geothermal power plants in Nevada, see Geothermal Resources Council Bulletin, March 1988, p. 1. 
However, the late 1970s saw two major changes which complicated greatly the transmission planning in the northern part of the state. First, a number of municipal utilities that had traditionally been power purchasers began to actively develop their own generating capacity, often built around geothermal energy. Second, a large number of small power generators and cogenerators began to appear in response to the terms of PURPA and the standard offers developed by the CPUC during 1983. Both of these groups--the public power firms and the small power operators--sought direct access to PG\&E's existing transmission and distribution system.

This is part of a larger issue, power wheeling, which affects not only geothermal developers but also publicly owned electric companies and/or private firms seeking cheap sources of power. Many small public utilities purchase the majority of their power, and often have access to relatively inexpensive federal power generated by hydropower. In periods of overall surplus capacity, large customers and public power agencies seek to use the lines of investor owned utilities to transmit inexpensive power that they have purchased. Investor-owned utilities are naturally very sensitive to losing control of the movement of power into and out of their service areas. 27

\subsection{The Transmission Needs of New Public Power Actors in The Geysers' KGRA}

A number of public power utilities began to explore the option of producing their own geothermal energy in the late 1970s. The most ambitious was the Northern California Power Agency (NCPA), a state agency founded in 1968 to represent 11 municipal electrical utilities

27 For a recent short analysis of the wheeling issue, see Sylvia Morrison, "Electric Rate Effects of Cogeneration and Wheeling: Should PURPA be Amended?" (Washington, D.C. Congressional Research Service Brief 87-119, September 10, 1987). 
and one irrigation district 28 in all phases of their electric power planning, purchase, generation, transmission, distribution, and sale. Some of the complex negotiations undertaken by NCPA in obtaining geothermal resource rights are described in Appendix A. The NCPA was joined by the Sacramento Municipal Utility District (SMUD), the California Department of Water Resources (CDWR), and the Modesto Irrigation District in their interest in developing baseload geothermal power plants at the Geysers' KGRA.

In the spring of 1983, the NCPA brought on-1ine the second public power geothermal plant in the Geysers' KGRA, a 110-MWe plant financed in part by a $\$ 45$ million Department of Energy geothermal loan guarantee. 29 While the power produced by NCPA Geothermal No. 1 plant was initially sold to PG\&E, on September 14, 1983 PG\&E agreed to wheel the NCPA geothermal power to its city members' power systems. ${ }^{30}$ However, with the addition of this plant, as well as the two 63 MW Coldwater Creek units brought on-line by the Central California Power Authority (CCPA) on June 1, 1988, it was clear that the PG\&E transmission capacity was going to be insufficient. Moreover, the initial wheeling arrangements for NCPA Plant No. 1 were on a short-term basis, with the possibility that some of the geothermal power might have to be curtailed if the PG\&E system became overloaded.

28 The major participants in NCPA were the cities of Santa Clara and Alameda. Other NCPA jurisdictions involved in the geothermal developments in Geysers' KGRA were Biggs, Girdley, Healdsburg, Lodi, Lompoc, Palo Alto, Plumas-Sierra, Roseville, and Ukiah. The city of Redding, a NCPA member, chose not to participate in the geothermal development. Geothermal Report, March 1, 1984, p. 3.

${ }^{29}$ Geothermal Report, Vo1. 13, No. 5, March 1, 1984, p. 1. The reader should note that this plant was originally called NCPA Geothermal No. 2, but was subsequently renumbered when the other plant was never constructed.

${ }^{30}$ Geothermal Report, July 16,1984, p. 3. 
Planning among the interested public power utilities began in the spring of 1984 and proceeded through 1985 for the creation of a 60-mile-long dedicated 230-kVa line to channel the geothermal power to customers in northern California (mostly in the Sacramento area) via a connection with a Western Area Power Authority substation nears Williams. However, the process for working out joint studies between PG\&E and the public power consortium dragged on through much of 1986 and early 1987, as the permitting process continued. Finally, in early February 1987, the CEC approved the application for certification for the Geothermal Public Power Line (GPPL), with its completion time being tentatively set for 1990.31 It was a continuation of the state-encouraged process of reducing the control that PG\&E had traditionally exercised over The Geysers' KGRA, and of increasing access to the area by wholesale power purchasers.

However, it was not until mid-summer 1988 that the GPPL received clearance for construction by the CEC, since the need for this additional transmission capacity was being studied until that time. Current estimates are for construction start-up in June 1989, but the 1990 completion date will almost certainly be delayed. 32 There appears to be less urgency for the early completion of the GPPL at the moment, since PG\&E has been willing to provide long-term wheel ing agreements to CCPA for its new Coldwater creek plants. However, the existing PG\&E transmission service agreement, with the GPPL member agencies, provides for only $140 \mathrm{MW}$ of capacity from The Geysers area, ${ }^{33}$ which does not allow for any future exparision.

$31_{\text {Geothermal Report, April 1, 1987, p. } 3 .}$

32 Geothermal Report, June 15, 1988, p.1; and August 15, 1988, p.2. ${ }^{33}$ Ibid. 


\subsection{Small Power Prcducers' Access to PG\&E Transmission Lines}

In February 1984, PG\&E announced that the growth in QF power in northern California was exceeding its capacity to transmit it to customers. Subsequently, PG\&E staff testified before the CPUC that contracts signed with QFs had increased from 204 to 6,593 MWe between 1980 and 1984, and the utility expected that the problem would be most severe in several of the northern California districts. To upgrade its lines to meet even a portion of this demand was estimated to cost $\$ 100$ million to $\$ 270$ million dollars, and the issue arose: who should pay for this investment? ${ }^{34}$ Hearings proceeded at the CPUC throughout 1985, focusing in good measure on the question of what portion of costs should the QF pay and what were legitimate charges to the ratepayers. Meanwhile, small power producers were charging that PG\&E was not providing information on its transmission problems and how these affected its ability to provide interconnections to interested QFs. Finally, after the CPUC served PG\&E with an order to produce additional information on its transmission problems or face fines, a compromise was worked out between PG\&E, small producer trade associations, and the CPUC staff. Independent producers were levied a $1.7 \mathrm{mills} / \mathrm{kWh}$ charge for interconnection, of which $1.2 \mathrm{mills}$ were refundable at a later date. 35 In the final decision, on September 18, 1985, the CPUC ruled that the utilities should be responsible for virtually all costs of transmitting QF power, with the small producers only paying the interconnect fee in the PG\&E service area. ${ }^{36}$ This was a major victory for all QFs, including private geothermal developers, seeking transmission service to distant markets.

${ }^{34}$ Geothermal Resource Council Bulletin, November 1985, pp. 11-12. ${ }^{35}$ Geothermal Report, JuTy 16, 1984, pp. 2-3.

${ }^{36}$ Geothermal Resources Council Bullet in, November 1985, pp. $12-13$. 


\subsection{THE BEOHAWE GEOTHERMAL PLANT: DIRECT EQUITY PARTICIPATION BY UNREGULATED SUBSIDIARIES OF UTILITIES IN PLANT DEVELOPMENT AND OPERATION}

On June 5, 1985, Chevron Resources joined forces with Crescent Valley Energy Company, a Southern California Edison (SCE) subsidiary to develop an integrated geothermal resource development/power plant project in north-central Nevada. Chevron assumed responsibility for well development, while Crescent Valley managed power plant construction. A 17-MWe gross, 14-MWe net power plant was built to use the $420^{\circ} \mathrm{F}$ resource in the Beowawe Geysers area, using a double flash modular turbine generator system. The plant is owned by Beowawe Geothermal Power Company, a joint venture of Chevron and crescent Valley, and operated by Chevron. 37

There are several aspects of this plant which have long-term implications for the geothermal industry, and therefore give it more importance than its small size and conventional design would indicate. First, the power was developed specifically to be sold to SCE by a group that includes one of its own unregulated subsidiaries as a major partner. Although the power plant is located in an adjoining state and is therefore outside the service area of the parent utility, it is still a pattern that geothermal developers find disturbing. Second, the partnership built an interconnect transmission line running from the Bishop power station to the SCE grid, so that the power wheeled by the local Nevada utility (SPPCO) can be delivered to SCE, the power customer. 38 This was apparently planned from the very start to take advantage of the higher power purchase price offered by SCE. Geothermal developers are disturbed

\section{p. 18. \\ ${ }^{37}$ Geothermal Resources Council Bullet in, July/August 1985,}

$38 \mathrm{~W}$. Blockley, "Northern Nevada's Geothermal Power Plants, " in EPRI Geothermal Conference and Workshop Seminar Notebook (Oakl and California: Electric Power Research Institute, June 23-25, 1987), [no page number]. 
at having the utility subsidiary planning from the outset to sell its output to its parent corporation, particularly in a time of 1 imited demand expansion and large number of proposed private power plants. Geothermal developers argue that the power company would certainly give preferential treatment to its own subsidiary, but that this one is operating in the unregulated rather than regulated portion of the power market. 
PART FOUR: FINDINGS AND LESSONS FOR THE DEPARTMENT OF ENERGY AND FOR THE GEOTHERMAL INDUSTRY

\subsection{ASPECTS OF PURPA CENTRAL TO FUTURE GEOTHERMAL DEVELOPMENT}

The geothermal companies contacted for this paper have found PURPA essential to their development and growth. They see the rapid growth of installed non-utility geothermal capacity directly linked to the projections and opportunities offered by the law and by the rule-setting procedures in key states. There is also acknowledgement that change is coming for QFs, in good part due to the success of private developers and cogenerators in adding thousands of megawatts of capacity to the existing utility grid network.

The geothermal developers contacted saw five key characteristics of PURPA that are essential if private developers are to have a major future role in geothermal power plant development: unregulated status, guaranteed access to power markets, avoided cost payments, long-term contracts, and guaranteed access to existing transmission facilities. Losing any or all of these privileges granted under PURPA would make it difficult for geothermal developers to operate.

Unregulated status is crucial for two different reasons. The first is largely institutional: the developer must be entrepreneurial to survive. The developers contacted indicated that many of them are too small and thinly staffed to financially support the reporting practices and public oversight that is inherent in regulated utility status. The second problem is financial: substantial rates of return are required to offset the developer's initial risks, leasing costs, and site development expenses, as well as to attract third-party investments in resource development, gathering systems, fower plants, and transmission systems. This is particularly true for a baseload technology such as geothermal, where the cost for the power plant alone often exceeds $\$ 100$ million for an 80-MWe PURPA plant. 
Guaranteed access to power markets and avoided cost payments allows the developer and any institutional backers to examine the expected stream of revenues from power and/or steam sales over the life of a given project and to compare it with the expected costs. It 1 imits uncertainty on the revenue side, which aids the developer in attracting financing. It also allows the developers to compare alternative power plant configurations at the same site, alternative projects in the same geothermal field, or even projects in different states to determine which is the best investment.

Several California developers interviewed candidly admitted that the S04 may have proved to be too generous, due to the unexpected recent drop in the price of oil and natural gas, but they felt that the underlying concept was sound: an initial fixed price for a certain period of time and then avoided cost or some formula tied to power generation costs. Most geothermal developers contacted feel that more competition among QFs is inevitable, but that this still should lead to a situation in which the final winner or winners are awarded power contracts at a known and fixed price. Most of those contacted are not in favor of contracts tied to external factors that are not predictable (fuel oil prices, the consumer price index, etc.). It was pointed out that geothermal plants are much more like nuclear or hydro $p l$ ants than natural gas cogeneration plants. The cost of resource for a geothermal facility is established in advance and relatively predictable for the 20- or 30-year life of the facility. Major increases in OPEC prices or a sudden natural gas shortage will not alter the delivered price of geothermal electricity, which makes it more desirable than a similarly sized natural gas turbine unit.

Long-term contracts are central to most developers' strategies, for they make possible the financing of the expensive resource development work, permits, and site development work. While several individuals interviewed were comfortable with more innovative power pricing programs (tied, for example to the price of a market basket 
of fossil fuels), most need a 15-30 year commitment from the utility purchasing the power to undertake project design and project financing. Once again, the geothermal industry contacted (and many state regulators) feel that this long-term commitment by the utility is proper, since geothermal power plants are baseload, with availability factors far exceeding that of the utility's own conventionally fueled plants, and with an anticipated life span equal to that of most current coal-fired power plants.

\section{Guaranteed access to existing transmission facilities is} important to all QF developers, but crucial to geothermal firms because of the size and capital intensity of most of the system currently being installed. A 230 MWe installation, such as the California Energy Corporation complex under construction at cosO Hot Springs KGRA, provides a major power increment even for a grant utility such as Southern California Edison. Moving this power over the main trunk lines of the utility is crucial to the financial viability of the project. For small installations, such as a number of the binary plants, even the interconnect charges we formidable obstacles, and the construction of dedicated transmission lines would be financially prohibitive.

Beyond these five essentials, the geothermal industry and state regulators feel certain that sweeping changes will alter the power industry and the QF sector in particular in the next five years. Bidding, in some form or another, is seen as being inevitable until the current glut of QF applications is eliminated. Erosion of the fully avoided cost power sales price will most likely occur, either through an auction process or some other similar mechanism. 


\subsection{IMPACTS OF PURPA ON THE SIZE AND TYPE OF GEOTHERMAL INSTALLATIONS CONSTRUCTED IN THE UNITED STATES: CUSTOM DESIGNED PURPA PLANTS}

While the focus of this report has been on the financial and contractual results of PURPA and the state rule-setting process, there have been a number of engineering observations and PURPA plant design statements that have been raised that might be useful to the reader for evaluating the implications of PURPA on geothermal technology. These are summarized below.

For many technologies, the impact of the PURPA and FERC guidelines on what constitutes a $Q F$ was minimal. Most renewable energy technologies qualified easily, and indeed many fell under the expedited handling developed by states like California for very small power plants (under $100 \mathrm{~kW}$ ). However, U.S. geothermal systems unti1 the advent of PURPA had been sized to conform to the standard operating modules of PGEE, the major utility purchasing geothermal power at that time. If the resource base at any given site was adequate, there was no particular constraint on the size of the system other than availability of financing, local power demand, and 1and. In traditional power plant planning, larger systems offer some additional operating efficiencies, and are normally preferred by utility operators. When the Northern California Power Authority designed its first geothermal plant at The Geysers, it settled on a two-phase 220-MWe system.

For a private geothermal developer, however, the PURPA size limitation of 80 Whe for a qualifying facility became a major plant design consideration. Thus, 80 MWe became the maximum size of a standard unit. When Occidental Geothermal and Stone and Webster developed the conceptual design for their first Geysers KGRA plant, it was sized to yield 80 -WWe net power output. It is too early to tell if this PURPA-imposed 1 imit has affected the growth of the technology, but it has certainly appears to have affected the design 
process. Since PURPA only affects private developers, and not utilities building their own units, there is now a two track system design process:
PURPA Units
designed for virtually $100 \%$ on-1ine availability and no more than 80 -MW output, and
Utility Units -

\begin{abstract}
which are designed to meet the particular power requirements and financial constraints of this individual utility.
\end{abstract}

\subsection{THE CREATION OF NEW MANAGERIAL AND FINANCIAL ARRANGEMENTS TO MANAGE THE "PURPA" GEOTHERMAL POHER PLANT}

Prior to PURPA, geothermal development was largely restricted to geophysical exploration and drilling. These activities were funded from retained earnings from previous sales, from limited partnerships, and from equity offerings as had been the case for oil and gas development. However, the opportunity provided by PURPA to move into power generation and power plant construction created a whole new range of required expertise in plant permitting, power plant construction planning, plant financing, plant operation, and utility interconnection. Most geothermal companies did not have this expertise in-house, nor did they want to undertake the financial risk of large ( $\$ 75$ million to $\$ 120$ million) construction activities.

Therefore, new consortia were developed consisting of resource developers, power plant architectural and engineering firms, commercial lenders, and often the local utility as we11. The complexity of these arrangements can be seen in the diagram below of the management for the Heber Double Flash Geothermal Power Plant, a 52-MWe gross (49 Whe net) installed facility developed jointly by Chevron Geothermal Company of California and the Heber Geothermal Company, which was itself a joint venture of Dravo Energy Company and Centennial Geothermal Company. Today the geothermal developer must 
be able to raise substantial construction funds, allocate investment and depreciation tax credits, provide for wheeling of power to the ultimate user, and locate long-term financing for the ownership of the power plant. 
FIGURE 1

ORGANIZATIONAL CHART FOR THE

HEBER DOUBLE FLASH GEOTHERMAL POWER PLANT

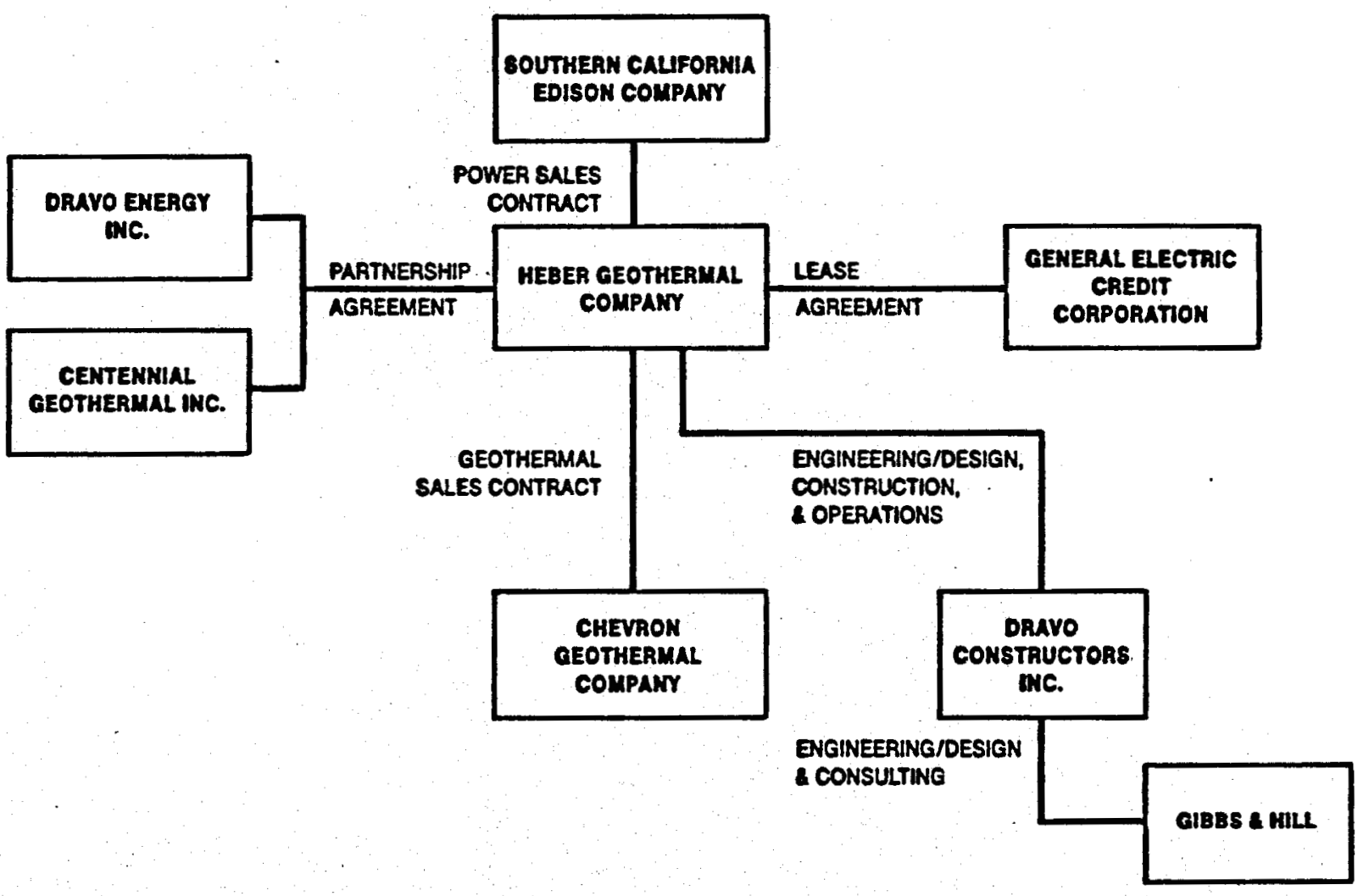

Source: Proceedings of the Geothermal Program Review III, October $16-19,1984$ quoted in PURPA Influence on Contemporary Geothermal Plants: Case Studies 1986 (Washington State Energy Office and Oregon Department of Energy for Bonneville Power Administration, February 1987 draft), p. A-47. 
APPENDIX A: EXAMPLES OF NEU U.S.

GEOTHERMAL PLANTS IN THE POST-PURPA ERA

\section{Santa Fe/Occidental Geothermal Plant \#1: The PURPA Plant in the Iraditional Geysers' KGRA Setting}

A. The Genesis of the Occidental Involvement at Geysers

Occidental Geothermal obtained leases for exploration and development in The Geysers KGRA in the mid-1970s, initially with the concept of selling steam to PG\&E as Union 011 had already been doing. It eventually assembled a 550-acre lease in Lake County, which contained high-quality steam resources. However, with the passage of PURPA, the firm began to explore the possibility of receiving a permit to produce power and sell it to the utility. The team settled upon a design that would produce the maximum power allowable under PURPA, and examined alternative designs primarily from their impacts on profitability and power sales. By February 1982, Occidental had received the 1 icenses required for operation, and shortly afterward began construction on an 80-MW power plant. The plant was completed in slightly over two years, and has been operational since April 1984. In November 1984, Occidental Geothermal was purchased by Santa Fe International and renamed Santa Fe Geothermal, Inc. To avoid confusion, the geothermal plant will be referred to in this report by both its current and old name, i.e., Santa Fe/Occidental Geothermal P1ant \#1.

B. The Implications of Unified Resource/Power Plant Operations for Geothermal Plant Design and Operation

Unlike the 19 previous geothermal power plants at The Geysers, the Santa $\mathrm{Fe} /$ Occidental installation was designed from its inception as an integrated resource/power plant. The development and supply of the steam, as well as the production of power, was undertaken by the same firm, rather than by a separate resource firm and a utility. 
This led to two new design principles which were to be found in other later PURPA-related geothermal installations.

- Efficiency: to ensure the needed rate of return on the capital investment in field development, the project designers sought to maximize the power produced per unit of steam. While actual efficiency of the installation is proprietary, it is estimated to be between 13-17 ibs steam $/ \mathrm{kWh}$, which is below the $20 \mathrm{lbs} / \mathrm{kWh}$ that had traditionally been found in Geysers' plants.

- Power Availability: in the design phase continuous availability of power for sale to the grid was considered even more important than overall system efficiency. The turbine/generator package was designed as two parallel systems, in which each normally provides 48.5 Whe of power at 115 pounds per square inch (PSI) of pressure. During scheduled maintenance or during unexpected downtime, either of the turbine trains can be operated at 88.2 MWe output at 165 PSI. Therefore, the maximum allowable PURPA output of 80 MWe can be maintained at all times. Indeed, during the first year of operation, the Santa Fe plant achieved a spectacular $99.9 \%$ availability and a $98.6 \%$ capacity factor.

This redundant design of turbines, generators, and some of the auxiliary equipment added approximately $\$ 5.2$ million to the overall system price. Also, whenever one turbine was used to produce all 80 MW of net power, the hourly steam demand increased from $1,300,000$ to $1,500,000$ pounds. However, the design team determined that if this feature only prevented two weeks of downtime per year, it would pay for itself from the increased revenue and capacity payments. Downtime has been virtually nonexistent, leading to an increased revenue stream that is not known but estimated to be as much as $20 \%$ higher than a single four-flow turbine.

- Attractiveness of the Physical Plant to Utility Purchasers: Another part of the Santa Fe/Occidental Geothermal design criteria which sets a PURPA plant apart from a utilityowned operation is that the overall unit was deliberately designed to be attractive to potential purchasers at a later date. The design team was instructed to develop all aspects of the resource gathering and power production system so that a utility would find it an attractive investment, in keeping with its construction standards, and 
fitting with its standard modes of operation.

C. The Importance of the Predictable Revenue Generation for the Geothermal Owner/Operator under PURPA

Occidental negotiated directly with PG\&E on a long-term power sales contract, and agreed upon a rate that was somewhat lower than the S04. While lower, the rate was quite attractive, being approximately 6 cents/kWh. It allowed the Stone and Hebster design engineers employed by occidental to determine the revenue stream for the life of the power plant, and to then conservatively design the plant to make certain the client's required return on investment was met even under unexpected contingencies. Several analysts noted that this ability to predict revenue streams is particularly important when third-party financing is used, as in the Heber Double Flash Geothermal project.

D. The Increased Rate of Return to the Developer Due to PURPAMandated Power Purchase Rates

Because of the direct negotiations of the resource/plant operator with the utility and the proprietary nature of the production cost, it is difficult to assess if the existence of PURPA has increased the rate of return of the developer over that of nearby Geyser operators, although it has certainiy increased the cash flow. If we assume that the plant has a steam consumption of $15 \mathrm{lbs} / \mathrm{kWh}$, then steam flow is approximately $1,200,000 \mathrm{lbs} / \mathrm{hr}$. For the power sales, Santa Fe receives approximately $\$ 60$ per $M W h$, or $\$ 115,000 /$ day. Nearby, Geysers Geothermal receives $\$ 1.33$ per 1,000 1bs of steam sold to the utility. For the same steam flow rate of $1,200,000 \mathrm{lbs} / \mathrm{hr}$, Geysers Geothermal is paid by PG\&E approximately $\$ 38,300 /$ day. However, Santa $\mathrm{Fe}$ also has to maintain and operate the plant, as well as amortize its substantial investment ( $\$ 94$ million dollars) in the power plant. 
11. The Mammoth Pacific/Ben Holt Binary Wellhead Power Plant: High PURPA Rates Bring Lower Grade Resources into Commercial Exploitation

A. Origins of the Ben Holt-Magma Cooperation and Involvement

The Manmoth Pacific plant is located on land owned by Magma Power. Magma has agreed to provide a five-year exclusive use contract for the geothermal resource in exchange for a $20 \%$ royalty on power sales. The plant is owned and operated by a joint venture of Pacific Energy Resources (a Pacific Lighting group firm) and Mammoth Binary Power Company, a subsidiary of the Ben Holt Company. The plant contains two air-cooled 8.5-MWe binary plants, using moderate temperature $\left(330^{\circ} \mathrm{F}\right)$ geothermal brines rather than the preferred dry steam such as is found at The Geysers. The plant was financed by the owners at a cost of approximately $\$ 10$ million $(\$ 13.5$ million if the wells and gathering system are included).

\section{B. Power Sales Contract}

The power generated by the plant is sold to SCE at very advantageous prices. For the first four years of operation, the owners are paid $12-1 / 2$ cents $/ \mathrm{kWh}$. This is then changed to avoided cost for two years, and then a rate of 6 cents/kWh until the frontend premium is paid back to the utility. With such a favorable rate (negotiated prior to the creation of SO4), the developers could use the lower quality geothermal resource, design the system for high power availability, pay Magma Power their desired royalty rate, and still make an acceptable rate of return on investment.

C. Implications of PURPA Mandated Rate Structures for the Design and Operation of the Plant

Just as in the Santa Fe/Occidental plant, there is a major incentive for the developer/owners of the Mammoth Pacific plant to 
maximize their cash flow from power sales. This is particularly true because of the front-end loaded nature of the sales contract, which provides very high prices for power sales in the first 48 months of operation. This led to one design and one operating principle:

- Power Availability: in the design phase continuous availability of power for sale to the grid was considered even more important than overall system efficiency. Therefore, two turbine generators were installed and two separate cooling towers were built, so that power could continue to be produced during scheduled or unexpected downtime. While the plant has had a substantial number of mechanical failures, its availability has been approximately $95 \%$.

- Increased Unit Power Sales at the Cost of Optimal Efficiency: to ensure maximum capital recovery in the initial years of the power sales contract, the plant operators have increased the throughput of brine from the planned 2,800 gallons per minute $(\mathrm{gpm})$ to $3,800 \mathrm{gpm}$. While this is less efficient, since it extracts less heat from each unit of brine, it does increase the power output per unit time. As a result, the plant has been producing at 5$15 \%$ over its design capacity.

III. Desert Peak Power Plant: PURPA helps to Move Geothermal Out of California into Other States

A. Origin of the Project Proposal

The Nevada Pub? ic Utilities Commission approved several experimental pilot geothermal plants. One of these was the Desert Peak plant, being developed by Chevron Geothermal and completed in 1986. This plant uses a biphase rotary separator turbine to extract power from the moderate temperature $\left(325^{\circ} \mathrm{F}\right)$ fluid.

B. Power Sales Contract

Because of the experimental nature of the system installed at Desert Peak, the utility SPPC, (a relatively small system) provided 
Phillips Geothermal with a price ( 6 cents $/ \mathrm{kWh}$ ) that is above the standard 5 cents/kWh PURPA avoided cost rate. There is also a premium for higher power availability, although it is not known if it is provided to the Desert Peak plant.

From material received from Sierra Pacific and from testimony by SPPC senior management, it is clear that the utility is not a strong supporter of federally mandated QF purchases, particularly those in the 5-6 cents/kWh range. The utility would much rather purchase lowcost surplus power from nearby coal or hydropower-based systems or construct its own baseload plants. Without the existence of PURPA and strong state regulatory pressure, it is doubtful if the geothermal developers would have received anything close to the power purchase price and the length of contract that they did obtain.

C. Implications of the Unified Resource/Power Plant Ownership and the Power Purchase Price for Power Plant Design and Operation

Chevron Geothermal is both the resource owner and the power plant owner/operator at Desert Peak. There is therefore a strong incentive, just as was seen in the case of Santa Fe/Occidental Plant, to extract the maximum amount of power from the developed geothermal resource. As the recent Washington State Energy Office/Oregon Department of Energy report noted (see pp. 18-19), careful design work and the weighing of alternative configurations resulted in a system that was more efficient than either a double or single flash unit, while being considerably less expensive and equally as efficient as a binary unit. Moreover, the power purchase price was high enough that the developer could install a relatively untried technology on a moderate temperature resource and still earn a modest rate of return on the investment. 
IV. Grace Geothermal vs. Northern California Power Authority: The Value of the Underlying Resource Reserve under PURPA Legislation

A. The Background of the NCPA Power Program in The Geysers' Known Geotherma7 Resource Area (KGRA)

The NCPA is a consortium of 11 municipal electric utilities and one rural electric cooperative. In the mid-1970s, the NCPA began to search for additional sources of power for its participating utilities and settled upon geothermal and hydro as attractive options. In late 1977, NCPA agreed to purchase steam from the Shell Oil company extracted from federal leaseholdings in The Geysers' KGRA. NCPA then proceeded to detailed engineering design for a 110MWe, \$85 million geothermal plant, called NCPA No. 2, as well as preliminary permitting for a second 110-MWe plant (NCPA No. 3) if additional steam resources proved to be available.

In September 1983, the Shell federal leaseholdings were bought by Grace Geothermal Corporation for $\$ 106 \mathrm{million}$, at which point Grace also assumed the existing NCPA steam contracts for NCPA No. 2 and for one of the 55-MWe turbines of NCPA No. 3. In addition, Grace agreed to provide steam for the second unit of NCPA No. 3, bringing the total to enough steam to produce 220 MWe of electric power.

Within a year, Grace and NCPA agreed that NCPA would take over the steam lease for $\$ 145$ million. Shortly thereafter, however, Grace abrogated the early agreement for the second block of steam for NCPA 3. NCPA then initiated a proceeding to condemn the property, using its power of eminent domain, in parallel to the continued efforts to settle the lease purchase from Grace.

The use of condemnation proceedings was a novel approach to forcing Grace to comply with the terms of the original agreement, especially since the negotiations between NCPA and Grace until that time had been primarily commercial in nature. A great deal of legal 
activity followed, and an effort to settle the case amicably failed when Grace stockholders turned down the proposed $\$ 145$ million steam lease. After nearly a year of legal maneuvering, court appeals, and counter suits, NCPA and Grace finally agreed on a steam lease sale for a reported $\$ 165$ million.

B. The NCPA Principle of Buying Steam Rather Than Power and its Implications Both for Geothermal Development and for Required Capital Investment

One of the most interesting aspects of the NCPA-Grace contract was that the contract called for NCPA to pay for the steam delivered on a poundage basis, whereas PG\&E pays Union $0 i 1$ in the same field on the basis of the power produced. Because of the steam purchase contract terms, NCPA has a strong financial incentive to install highly efficient turbines and balance of systems, in order to extract the maximum amount of power from each unit of purchased steam. For example, the NCPA planners estimate that the NCPA Geothermal No. 2 use 15 lbs of steam per kilowatt-hour produced, while the PG\&E systems using the same resource base require $20 \mathrm{lbs}$ of steam per kilowatt-hour of electricity generated. 